\title{
Microbiology, Biochemistry, and Volatile Composition of Tulum Cheese Ripened in Goat's Skin or Plastic Bags
}

\author{
A. A. Hayaloglu, ${ }^{11}$ S. Cakmakci,† E. Y. Brechany,‡ K. C. Deegan, $\S$ and P. L. H. McSweeney§ \\ ${ }^{*}$ Department of Food Engineering, Engineering Faculty, Inonu University, 44280 Malatya, Turkey \\ †Department of Food Engineering, Agricultural Faculty, Ataturk University, 25240 Erzurum, Turkey \\ fFood Quality and Safety Group, Hannah Research Institute, Ayr, KA6 5HL, United Kingdom \\ $\S$ Department of Food and Nutritional Sciences, University College, Cork, Ireland
}

\begin{abstract}
Tulum cheeses were manufactured from raw ewe's milk and ripened in goat's skin bags (tulums) or plastic containers to understand the effect of ripening container on the chemical composition, biochemistry, microbiology, and volatile composition of Tulum cheeses during $150 \mathrm{~d}$ of ripening. Chemical compositions of the cheeses ripened in tulums were significantly different and the moisture contents decreased rapidly in those cheeses because of the porous structure of the tulum. Higher microbial counts were detected in the cheeses ripened in plastic than in cheeses ripened in tulums. Differences in nitrogenous compounds and total free AA of the cheeses were not significant. Total concentrations of free AA in cheeses increased with age and Glu, Ala, Val, Leu, and Phe were the most abundant AA in the cheeses. Urea-PAGE of $\mathrm{pH}$ 4.6-insoluble fractions of the cheeses during ripening showed similar degradation patterns in all cheeses. Peptide profiles by reversed-phase HPLC of $\mathrm{pH}$ 4.6- and ethanol-soluble or ethanol-insoluble fractions of the cheeses revealed only minor differences in the concentrations of some peptides among the cheeses; however, age-related changes in peptide concentrations were significantly different among the cheeses. Cheeses were analyzed at $90 \mathrm{~d}$ of ripening for volatile compounds by solid-phase microextraction gas chromatography-mass spectrometry. One hundred volatile components were identified, including 11 acids, 16 esters, 12 methyl ketones, 7 aldehydes, 22 alcohols, 7 sulfur compounds, 6 terpenes, and 19 miscellaneous compounds. The main components were short-chain fatty acids, 2-butanone, diacetyl, and primary alcohols. Quantitative differences in several volatile compounds were evident among the cheeses. Cheeses ripened in tulums or plastic had similar aroma patterns, but the concentrations of some components were different.
\end{abstract}

Received May 17, 2006.

Accepted October 30, 2006.

${ }^{1}$ Corresponding author: ahayaloglu@inonu.edu.tr
Key words: Tulum cheese, packaging material, volatile composition, ripening and proteolysis

\section{INTRODUCTION}

Cheese ripening is a complex and dynamic biochemical process that includes protein breakdown, fat hydrolysis, and lactose and lactate metabolism (El Soda et al., 1995; McSweeney and Sousa, 2000). Proteolysis is catalyzed by proteolytic enzymes from the coagulant, milk, and bacteria (starter, secondary starter, or nonstarter). The coagulant is mainly responsible for hydrolyzing the $\mathrm{CN}$ to large and intermediate-sized peptides (Law et al., 1992; Lane and Fox, 1997). Enzymes originating from starter (i.e., proteinases, peptidases) play major roles in the formation of small peptides and AA, which serve as precursors of flavor compounds in the cheese (Urbach, 1997).

Many cheese varieties that are produced only in restricted geographic areas of the world are consumed locally in large quantities. More than 50 varieties of cheese can be found in Turkey; however, 3 of them (Beyaz, Kasar, and Tulum cheeses) are the most popular. The annual production of Tulum cheese was 10,000 tonnes in 2004 (data from the Turkish Statistical Institute, Ankara, Turkey). Its production has increased greatly, and this trend has continued over recent years in a number of cheese plants.

According to the description by Kurt et al. (1991a), Tulum cheese has a white or cream color, a high fat content, and a crumbly and semihard texture; it is dispersible in the mouth and has a buttery and pungent flavor. The name tulum means "goat's or sheep's skin bag" in Turkish, which is the bag used for packaging and ripening. In general, there are 2 kinds of Tulum cheese: One is Izmir Brined Tulum, which is produced in the western region of Turkey, and the second is Erzincan Savak Tulum, which is produced mainly in the eastern region of Turkey. The latter is made in the mountains and plateaus of Erzincan, Erzurum, Tunceli, Bingol, and Elazig and in the East Anatolian regions by the Savak tribe, and was originally ripened in tulums 
in caves for at least $3 \mathrm{mo}$. When people say "Tulum cheese" in Turkey, they imply Erzincan Savak Tulum cheese. Therefore, the term "Tulum cheese" is used throughout the text to refer to Erzincan Savak Tulum cheese. Goat's skin bags are stronger than sheep's skin bags and tulums are permeable to water and air because of their porous structure. In the past, the tulum was probably used for cheese packaging because of the absence of alternative packaging materials for preserving and ripening the cheese. Nowadays, hardened plastic barrels have been used for ripening the Tulum cheese.

Studies on Tulum cheese are limited; however, some research has been focused on this variety in the last decade. These works have concentrated on the chemical and microbiological status of Tulum cheeses sold in Turkish markets. Few studies are available on the effect of different packaging materials on the microbiological and chemical characteristics of Tulum cheese. The microbiological qualities of Tulum cheeses ripened in goat's skin or polyethylene bags were compared by Guven and Konar (1994a). Similarly, Sengul et al. (2001) studied the effect of packaging materials (wooden box, goat's skin, or polyethylene bag) on the microbiology of Tulum cheeses during ripening. The use of different types of milk (cow's, ewe's or goat's milk) in the manufacture of Tulum cheese was compared by Guven et al. (1995), who reported that the type of milk significantly influenced the microbiology of Tulum cheese during 210 d of ripening. Sengul and Cakmakci (1998) used polyethylene bags and wooden materials as alternatives to a tulum, and the authors emphasized that the use of different packaging materials had an effect on the chemical and microbiological qualities of the Tulum cheese; however, they recommended further studies to determine the best packaging material. Although raw milk has continued to be used for Tulum cheese making, Bostan and Ugur (1991) and Sengul et al. (2001) have recommended using pasteurized milk and a starter culture.

The studies mentioned relate to only the composition and microbiological status (hygienic aspects) of Tulum cheese. Some authors (Guven and Konar, 1994a, 1995; Sengul et al., 2001) have pointed out that ripening in tulums or polyethylene bags significantly influences the chemistry and microbiology of Tulum cheese during ripening. According to consumers, the cheese ripened in tulums has a superior quality in comparison with the cheese ripened in plastic barrels. Furthermore, because of increasing interest in traditional cheeses in Turkey and many other countries, new studies are needed to better understand the role of proteolysis and the volatile composition of the cheese, including characterization of the electrophoretic patterns and peptide profiles, and determination of the levels of volatile compounds. To the authors' knowledge, no other researchers have previously attempted to characterize in detail the proteolysis and volatile profile of Tulum cheese.

In this study, urea-PAGE was performed to determine the extent of primary proteolysis in Tulum cheese, and nitrogen fractions, individual $\mathrm{AA}$, and peptides were analyzed to determine secondary proteolysis. Gas chromatography-mass spectrometry was used to quantify flavor compounds to compare Tulum cheese ripened in goat's skin or polyethylene bags during ripening. In addition, the typical properties of the cheese, the manufacturing procedure, the composition, and microbiological counts of Tulum cheese are described.

\section{MATERIALS AND METHODS}

\section{Materials}

Fresh ewe's milk (200 L) was obtained from 2 different farmhouses on the Baskurtdere plateau, Ilica, Erzurum, Turkey. Homemade rennet, called sirden in Turkish, was obtained from the farmers. Tulums (goat's skin bags) with a capacity of $10 \mathrm{~kg}$ of cheese were obtained from the farmers. Plastic materials (hardened cylindrical barrels), also with a 10-kg capacity, were obtained from local markets.

\section{Homemade Rennet Manufacture}

Rennet was made using the following traditional method. Cleaned young calves' stomachs were air-dried while shaded from the sun, cut into slices, and then placed in whey containing approximately 10\% (wt/vol) $\mathrm{NaCl}$. After 1 to $2 \mathrm{wk}$, the rennet extract (prepared by blending macerated stomach slices in the $\mathrm{NaCl}$ solution) was clarified (filtered) using a cotton material, and the filtrate was used as a coagulant.

\section{Cheese Making}

Tulum cheese (Erzincan Savak type) was made from raw ewe's milk (200 kg) in Erzurum Province (Baskurtdere plateau, Ilica, Erzurum, Turkey). The milk was acidified by its native microflora. The homemade calf rennet was added at a level of $1.0 \%$ (vol/vol), and coagulation took place at $35^{\circ} \mathrm{C}$. The coagulum was cut into pieces (approximately 1-cm cubes) and transferred into cotton bags for whey drainage. Drainage was carried out at $20^{\circ} \mathrm{C}$ for $24 \mathrm{~h}$, and the curd was pressed by piling the cotton bags on top of each other, with regular turning. Stacking of the curd at this temperature allows curd acidity ( $\mathrm{pH}$ drops below 6.0) to develop and increases the removal of whey. Following this step, the curd was broken into pea-size pieces by hand and salted 
$(3.0 \%, \mathrm{wt} / \mathrm{wt})$, kneaded, and transferred into the bags. The bags were piled on top of each other and turned regularly for $10 \mathrm{~d}$. Afterward, the plastic barrels (cheeses P1 and P2) or tulums (cheeses T1 and T2) were tightly filled with curd at 2 different dairies ( 1 and 2 ), and the packaged samples were ripened for $150 \mathrm{~d}$. Cheese making was performed in duplicate, and the cheese samples were analyzed every $30 \mathrm{~d}$.

\section{Sampling}

The cheeses were stored in a refrigerator (working at 4 to $6^{\circ} \mathrm{C}$ ) and were sampled from the same skin bag $(10 \mathrm{~kg})$ or plastic barrel $(10 \mathrm{~kg})$ at each sampling time $(30,60,90,120$, or $150 \mathrm{~d})$ after the surface section (approximately 0.5 to $1.0 \mathrm{~cm}$ ) was discarded. After each sampling time, the skin was tied up tightly and stored again for further sampling. In plastic barrels, the surface of the cheese was covered with a nylon material after sampling.

\section{Chemical Analysis}

Cheeses were analyzed in duplicate for moisture by the gravimetric method (dried at $102^{\circ} \mathrm{C}$; IDF, 1982), for salt by titration with $\mathrm{AgNO}_{3}$ (Bradley et al., 1993), for fat by the method of Van Gulik (Ardo and Polychroniadou, 1999), and for total nitrogen (TN) by the Kjeldahl method (IDF, 1993). For $\mathrm{pH}$ measurement, grated cheese $(10 \mathrm{~g})$ was macerated with $10 \mathrm{~mL}$ of distilled water, and the $\mathrm{pH}$ of the resultant slurry was measured using a digital $\mathrm{pH}$ meter (model $420 \mathrm{~A}$; Orion, Beverly, MA). Titratable acidity was determined as grams of lactic acid/100 grams of cheese using the AOAC method (1995).

Water-soluble nitrogen (WSN), 12\% TCA-soluble nitrogen (TCA-SN), and 5\% phosphotungstic acid-soluble (PTA-SN) fractions, as the percentage of TN of the cheese, were determined by the methods described by Hayaloglu et al. (2005). Total free AA (FAA) levels in the $\mathrm{pH} 4.6$-soluble fraction of the cheeses were determined by the Cd-ninhydrin method of Folkerstma and Fox (1992). Individual FAA were determined in $12 \%$ TCA-soluble filtrates of $\mathrm{pH} 4$.6-soluble extracts using a Beckman 6300 High-Performance Amino Acid Analyzer (Beckman Instruments Ltd., High Wycombe, UK), as described by Hayaloglu et al. (2005). Concentrations were expressed as milligrams/100 grams of cheese. The $\mathrm{pH}$ 4.6-insoluble fractions of the cheeses were freezedried and then analyzed by urea-PAGE using a Protean II XI vertical slab gel unit (Bio-Rad Laboratories Ltd., Watford, UK) according to the method of Andrews (1983). The gels were stained directly with Coomassie brilliant blue G-250, following the method of Blakesley and Boezi (1977). The $\mathrm{pH} 4.6$-soluble nitrogen fractions of the cheeses and subfractions with $70 \%$ (vol/vol) ethanol were also freeze-dried and analyzed by reversedphase HPLC (RP-HPLC) as described by Hayaloglu et al. (2005).

\section{Microbiological Analysis}

For each cheese sample, $10 \mathrm{~g}$ was weighed, diluted aseptically in $90 \mathrm{~mL}$ of citrate buffer $(2 \%$, wt/vol), and homogenized in a sterile polyethylene bag using a Stomacher 400 (Seward Laboratory, London, UK) for 1.5 min. Serial dilutions were made in $0.1 \%$ sterile peptone water, and all determinations were made in duplicate. The enumeration of total mesophilic bacteria (Plate Count Agar; Merck Darmstadt, Germany) at $30^{\circ} \mathrm{C}$ for $48 \mathrm{~h}$ (Messer et al., 1985), total coliforms (violet red bile agar; Merck) at $37^{\circ} \mathrm{C}$ for $48 \mathrm{~h}$ (Hartman and La Grang, 1985), and yeasts and molds (potato dextrose agar; Merck) at $21^{\circ} \mathrm{C}$ for $7 \mathrm{~d}$ (Frank et al., 1993) were performed during the ripening of Tulum cheeses.

\section{Analysis of Volatile Components in Cheese Using Solid-Phase Microextraction}

Preparation of Cheese Samples. Cheese samples were sliced, frozen in liquid nitrogen, pulverized into small granules, and stored in glass bottles in a freezer at $-20^{\circ} \mathrm{C}$. A 3 -g portion of sample was then placed in a $15-\mathrm{mL}$ vial and allowed to equilibrate at $40^{\circ} \mathrm{C}$ for 30 min. Extraction of volatiles was carried out using a solventless extraction technique (Pawliszyn, 1997). The method is suitable for isolation of volatiles from the sample matrix and has been used in various configurations for the characterization of cheese samples. Essentially, extraction is achieved by injecting a $75 \mu \mathrm{m}$ carboxen-polydimethylsiloxane fiber (Sigma-Aldrich, Poole, UK) into the vial and exposing it to the headspace for $30 \mathrm{~min}$ at $40^{\circ} \mathrm{C}$. The fiber was positioned at 3.0 scale units in each run.

GC-MS Operating Parameters. Desorption of the extracted volatiles was carried out on an Agilent 5890 gas chromatography-5972 mass spectrometry system (Agilent, Stockport, UK) run in splitless mode. During desorption, the fiber remained in the injector for $2 \mathrm{~min}$ at a temperature of $250^{\circ} \mathrm{C}$, with helium as the carrier gas at a flow rate of $1.0 \mathrm{~mL} / \mathrm{min}$. The components were separated on an Agilent FFAP column $(50 \mathrm{~m} \times 0.2 \mathrm{~mm}$ $\times 0.33 \mu \mathrm{m}$; Crawford Scientific, Strathaven, UK). The oven was held at $40^{\circ} \mathrm{C}$ for 2 min (desorption period), then increased at $5^{\circ} \mathrm{C}$ per min to $70^{\circ} \mathrm{C}$, where it was held for $1 \mathrm{~min}$. The temperature was then raised at $10^{\circ} \mathrm{C}$ per min to $240^{\circ} \mathrm{C}$, to give a run time of $30 \mathrm{~min}$. The mass spectrometer was set to record 33 to $450 \mathrm{amu}$ (threshold 1,000) at a sampling rate of $1.11 \mathrm{scans} / \mathrm{s}$. 
Data Analysis by Solid-Phase Microextraction. Components were identified using the data obtained from the mass spectrometer in full-scan mode. A database was then set up to quantify relative amounts of each. The database was constructed using selected ion monitoring, with specific ions selected to allow quantification of coeluting peaks. Response factors were not used in quantifying the samples because these would require determination of the rate of release from the cheese into the headspace and the efficiency of extraction of each component. Thus, actual concentrations of the components in the cheese were not known, but for the purpose of this project, comparative values were used to show differences between the varying treatments. Instead, the data were in the form (area of peak/ $10^{5}$ ) and were normalized to a weight of $1 \mathrm{~g}$ of sample. These comparative data were then analyzed using ANOVA, whereby the mean response of the data, transformed to give the square root (SQRT), was calculated. Analysis of variance of the SQRT-transformed data was carried out using Minitab (version 13; Minitab, Coventry, UK) on the basis of cheese type.

\section{Statistical Analysis of Data}

A randomized complete block design that incorporated 4 treatments (cheese $\mathrm{P} 1, \mathrm{P} 2$, $\mathrm{T} 1$, or $\mathrm{T} 2$ ), 5 ripening periods (30, 60, 90, 120 , or $150 \mathrm{~d}$ ), and 2 blocks (trials) was used to analyze the response variables relating to cheese composition and proteolysis data. Analysis of variance was performed using the GLM procedure of SAS (SAS Institute, 1995), whereby the effects of treatment and replicates were estimated for the response variables. Duncan's multiple-comparison test was used as a guide for paired comparisons of treatment means. The level of significance of differences between treatments was determined at $P<0.05$.

\section{RESULTS AND DISCUSSION}

\section{Chemical Composition and $\mathrm{pH}$}

The acidity and $\mathrm{pH}$ values and the contents of moisture, salt-in-moisture, and fat-in-DM of the Tulum cheeses are given in Table 1. Titratable acidity was below $3.0 \%$ as lactic acid, as is specified in the regulation for Tulum cheese in Turkish standards (Turk Standartlari Enstitusu, 1995). The titratable acidity values in the cheeses were within the normal ranges during 150 $\mathrm{d}$ of ripening. The level of acidity in $\mathrm{T}$ cheeses was numerically higher than that in $\mathrm{P}$ cheeses except at 30 $\mathrm{d}$; however, these differences were not observed at each stage of ripening. The initial $\mathrm{pH}$ of the cheeses was approximately 4.8 . No significant changes were seen in $\mathrm{pH}$ values during the first $120 \mathrm{~d}$ of ripening, but the
$\mathrm{pH}$ increased rapidly thereafter, from 4.8 to $>5.2$ at 150 $\mathrm{d}$ of ripening. The highest and lowest $\mathrm{pH}$ values were recorded in $\mathrm{T} 1$ and $\mathrm{P} 2$ cheeses (5.48 and 5.05, respectively). The moisture contents of the cheeses were high early in ripening, between 49.28 to $53.99 \%$, and then decreased during ripening. The final values in the P1 and P2 cheeses were 48.77 and $48.06 \%$, respectively, whereas the final moisture values in the $\mathrm{T} 1$ and $\mathrm{T} 2$ cheeses were 37.17 and $31.60 \%$, respectively. The final moisture levels in $\mathrm{T}$ cheeses were acceptable for this cheese (Turk Standartlari Enstitusu, 1995). The loss of moisture was rapid in the $\mathrm{T}$ cheeses, which can be attributed to the porous structure of the tulum. Therefore, ripening in tulums caused more moisture loss in the $\mathrm{T}$ cheeses, and the ripening period had a significant effect on the moisture contents of those cheeses $(P<$ 0.05). The salt-in-moisture contents of the cheese increased during ripening; a rapid increase was observed in the T2 cheese, which reached $9.28 \%$ at $150 \mathrm{~d}$, whereas it was 4.12 and $4.31 \%$ in the $\mathrm{P} 1$ and $\mathrm{P} 2$ cheeses, respectively. Significant differences in the salt-in-moisture contents of the $\mathrm{P}$ and $\mathrm{T}$ cheeses were found throughout ripening $(P<0.05)$. The fat-in-DM contents were $>40 \%$ (wt/wt) and the cheeses could be categorized as full-fat Tulum cheeses according to the regulation for Tulum cheese (Turk Standartlari Enstitusu, 1995). The relative levels of total protein increased in the $\mathrm{T}$ cheeses during ripening because the moisture contents of the cheeses decreased. The highest levels were close to $16.7 \%$ for the P1 and P2 cheeses and were 19.8 and $21.3 \%$ for the $\mathrm{T} 1$ and $\mathrm{T} 2$ cheeses, respectively, at 120 $\mathrm{d}$ of ripening. No relationship could be found between dairy and the chemical composition and $\mathrm{pH}$ of the experimental cheeses during ripening.

\section{Microbiological Characteristics}

The microbiological characteristics of Tulum cheeses ripened in plastic or tulums were studied during 150 $\mathrm{d}$ of ripening (Table 2). In all cheeses, the highest levels of total mesophilic bacteria were found at the first stage of ripening, and their counts decreased until $120 \mathrm{~d}$. However, the counts increased sharply at the end of ripening $(150 \mathrm{~d})$, and the final values ranged from 6.15 to $6.74 \mathrm{log} \mathrm{cfu} / \mathrm{g}$ of cheese. A similar trend was reported by Caglar (2001) in cheeses ripened in tulums or in plastic bags. However, higher counts for total mesophilic bacteria were observed by Sengul et al. (2001) and Patir et al. (2001) in their studies on Tulum cheese.

Coliforms were also present in all samples, and their counts were close to $5.0 \mathrm{log} \mathrm{cfu} / \mathrm{g}$ at $30 \mathrm{~d}$ of ripening. The highest and lowest coliforms counts were noted in P2 and T1 cheeses, respectively (Table 2). The coliform bacterial counts were significantly higher in the cheeses 
Table 1. Chemical composition and $\mathrm{pH}$ of Tulum cheeses ripened in plastic $(\mathrm{P})$ or goat's skin bags (T) during ripening ${ }^{1}$

\begin{tabular}{|c|c|c|c|c|c|c|}
\hline \multirow[b]{2}{*}{ Variable } & \multirow[b]{2}{*}{ Days } & \multicolumn{5}{|c|}{ Cheese } \\
\hline & & & $\mathrm{P} 1$ & $\mathrm{P} 2$ & $\mathrm{~T} 1$ & $\mathrm{~T} 2$ \\
\hline \multirow[t]{5}{*}{ Titratable acidity $^{2}$} & 30 & 1.40 & $\pm 0.01^{\mathrm{a}, \mathrm{B}}$ & $1.40 \pm 0.06^{\mathrm{a}, \mathrm{A}}$ & $1.22 \pm 0.06^{\mathrm{b}, \mathrm{B}}$ & $1.35 \pm 0.03^{\mathrm{a}, \mathrm{B}}$ \\
\hline & 60 & 1.35 & $\pm 0.02^{\mathrm{a}, \mathrm{B}}$ & $1.22 \pm 0.02^{\mathrm{b}, \mathrm{B}}$ & $1.40 \pm 0.01^{\mathrm{a}, \mathrm{A}}$ & $1.40 \pm 0.00^{\mathrm{a}, \mathrm{AB}}$ \\
\hline & 90 & 1.53 & $\pm 0.03^{\mathrm{a}, \mathrm{A}}$ & $1.32 \pm 0.02^{\mathrm{a}, \mathrm{AB}}$ & $1.37 \pm 0.07^{\mathrm{a}, \mathrm{A}}$ & $1.43 \pm 0.07^{\mathrm{a}, \mathrm{AB}}$ \\
\hline & 120 & 1.37 & $\pm 0.01^{\mathrm{b}, \mathrm{B}}$ & $1.34 \pm 0.04^{\mathrm{b}, \mathrm{A}}$ & $1.44 \pm 0.06^{\mathrm{ab}, \mathrm{A}}$ & $1.53 \pm 0.01^{\mathrm{a}, \mathrm{A}}$ \\
\hline & 150 & 0.54 & $\pm 0.03^{\mathrm{b}, \mathrm{C}}$ & $0.63 \pm 0.04^{\mathrm{ab}, \mathrm{C}}$ & $0.72 \pm 0.01^{\mathrm{a}, \mathrm{C}}$ & $0.59 \pm 0.07^{\mathrm{b}, \mathrm{C}}$ \\
\hline \multirow{5}{*}{$\mathrm{pH}$} & 30 & 4.72 & $\pm 0.01^{\mathrm{c}, \mathrm{C}}$ & $4.79 \pm 0.00^{\mathrm{b}, \mathrm{B}}$ & $4.82 \pm 0.03^{\mathrm{b}, \mathrm{B}}$ & $4.88 \pm 0.01^{\mathrm{a}, \mathrm{B}}$ \\
\hline & 60 & 4.81 & $\pm 0.00^{\mathrm{ab}, \mathrm{B}}$ & $4.80 \pm 0.01^{\mathrm{b}, \mathrm{B}}$ & $4.87 \pm 0.00^{\mathrm{a}, \mathrm{B}}$ & $4.85 \pm 0.03^{\mathrm{ab}, \mathrm{B}}$ \\
\hline & 90 & 4.79 & $\pm 0.03^{\mathrm{b}, \mathrm{B}}$ & $4.78 \pm 0.01^{\mathrm{b}, \mathrm{B}}$ & $4.89 \pm 0.03^{\mathrm{a}, \mathrm{B}}$ & $4.86 \pm 0.01^{\mathrm{ab}, \mathrm{B}}$ \\
\hline & 120 & 4.76 & $\pm 0.01^{\mathrm{c}, \mathrm{BC}}$ & $4.77 \pm 0.00^{\mathrm{c}, \mathrm{B}}$ & $4.86 \pm 0.00^{\mathrm{a}, \mathrm{B}}$ & $4.83 \pm 0.01^{\mathrm{b}, \mathrm{B}}$ \\
\hline & 150 & 5.24 & $\pm 0.01^{\mathrm{b}, \mathrm{A}}$ & $5.05 \pm 0.07^{\mathrm{c}, \mathrm{A}}$ & $5.48 \pm 0.03^{\mathrm{a}, \mathrm{A}}$ & $5.32 \pm 0.01^{\mathrm{b}, \mathrm{A}}$ \\
\hline \multirow[t]{5}{*}{ Moisture, \% } & 30 & 51.96 & $\pm 0.13^{\mathrm{a}, \mathrm{A}}$ & $50.72 \pm 0.10^{\mathrm{b}, \mathrm{A}}$ & $53.99 \pm 0.10^{\mathrm{c}, \mathrm{A}}$ & $49.28 \pm 0.04^{\mathrm{d}, \mathrm{A}}$ \\
\hline & 60 & 51.17 & $\pm 0.07^{\mathrm{a}, \mathrm{B}}$ & $50.55 \pm 0.01^{\mathrm{b}, \mathrm{A}}$ & $44.60 \pm 0.01^{\mathrm{c}, \mathrm{B}}$ & $43.70 \pm 0.07^{\mathrm{d}, \mathrm{B}}$ \\
\hline & 90 & 48.96 & $\pm 0.07^{\mathrm{a}, \mathrm{C}}$ & $48.65 \pm 0.03^{\mathrm{b}, \mathrm{B}}$ & $41.05 \pm 0.09^{\mathrm{c}, \mathrm{C}}$ & $38.65 \pm 0.01^{\mathrm{d}, \mathrm{C}}$ \\
\hline & 120 & 48.93 & $\pm 0.14^{\mathrm{a}, \mathrm{C}}$ & $48.38 \pm 0.04^{\mathrm{b}, \mathrm{B}}$ & $40.94 \pm 0.18^{\mathrm{c}, \mathrm{C}}$ & $34.47 \pm 0.14^{\mathrm{d}, \mathrm{D}}$ \\
\hline & 150 & 48.77 & $\pm 0.08^{\mathrm{a}, \mathrm{C}}$ & $48.06 \pm 0.23^{\mathrm{a}, \mathrm{C}}$ & $37.17 \pm 0.52^{\mathrm{b}, \mathrm{D}}$ & $31.60 \pm 0.66^{\mathrm{c}, \mathrm{E}}$ \\
\hline \multirow[t]{5}{*}{ Salt-in-moisture, $\%$} & 30 & 2.70 & $\pm 0.06^{\mathrm{c}, \mathrm{C}}$ & $2.67 \pm 0.08^{\mathrm{c}, \mathrm{C}}$ & $4.19 \pm 0.07^{\mathrm{b}, \mathrm{C}}$ & $4.63 \pm 0.12^{\mathrm{a}, \mathrm{E}}$ \\
\hline & 60 & 3.44 & $\pm 0.01^{\mathrm{b}, \mathrm{B}}$ & $2.89 \pm 0.10^{\mathrm{c}, \mathrm{C}}$ & $3.14 \pm 0.02^{\mathrm{c}, \mathrm{D}}$ & $5.47 \pm 0.02^{\mathrm{a}, \mathrm{D}}$ \\
\hline & 90 & 4.10 & $\pm 0.04^{\mathrm{c}, \mathrm{A}}$ & $3.97 \pm 0.02^{\mathrm{c}, \mathrm{B}}$ & $5.00 \pm 0.13^{\mathrm{b}, \mathrm{B}}$ & $6.68 \pm 0.00^{\mathrm{a}, \mathrm{C}}$ \\
\hline & 120 & 4.10 & $\pm 0.14^{\mathrm{c}, \mathrm{A}}$ & $4.24 \pm 0.12^{\mathrm{c}, \mathrm{AB}}$ & $5.43 \pm 0.15^{\mathrm{b}, \mathrm{B}}$ & $8.15 \pm 0.20^{\mathrm{a}, \mathrm{B}}$ \\
\hline & 150 & 4.12 & $\pm 0.08^{\mathrm{c}, \mathrm{A}}$ & $4.31 \pm 0.16^{\mathrm{c}, \mathrm{A}}$ & $6.14 \pm 0.33^{\mathrm{b}, \mathrm{A}}$ & $9.28 \pm 0.46^{\mathrm{a}, \mathrm{A}}$ \\
\hline \multirow[t]{5}{*}{ Fat-in-DM, \% } & 30 & 58.81 & $\pm 0.89^{\mathrm{a}, \mathrm{A}}$ & $55.81 \pm 1.32^{\mathrm{b}, \mathrm{A}}$ & $52.79 \pm 1.21^{\mathrm{c}, \mathrm{C}}$ & $56.68 \pm 0.65^{\mathrm{ab}, \mathrm{B}}$ \\
\hline & 60 & 58.37 & $\pm 0.09^{\mathrm{a}, \mathrm{A}}$ & $55.61 \pm 1.00^{\mathrm{b}, \mathrm{A}}$ & $53.25 \pm 0.01^{\mathrm{c}, \mathrm{C}}$ & $51.96 \pm 0.50^{\mathrm{c}, \mathrm{C}}$ \\
\hline & 90 & 56.33 & $\pm 0.57^{\mathrm{b}, \mathrm{B}}$ & $56.48 \pm 0.04^{\mathrm{b}, \mathrm{A}}$ & $57.68 \pm 0.08^{\mathrm{a}, \mathrm{B}}$ & $57.05 \pm 0.01^{\mathrm{ab}, \mathrm{B}}$ \\
\hline & 120 & 56.30 & $\pm 0.53^{\mathrm{b}, \mathrm{B}}$ & $57.15 \pm 1.32^{\mathrm{b}, \mathrm{A}}$ & $58.00 \pm 0.42^{\mathrm{ab}, \mathrm{B}}$ & $59.52 \pm 0.13^{\mathrm{a}, \mathrm{A}}$ \\
\hline & 150 & 56.61 & $\pm 0.09^{\mathrm{c}, \mathrm{B}}$ & $57.76 \pm 1.11^{\mathrm{bc}, \mathrm{A}}$ & $60.49 \pm 0.50^{\mathrm{a}, \mathrm{A}}$ & $59.21 \pm 0.06^{\mathrm{ab}, \mathrm{A}}$ \\
\hline \multirow[t]{4}{*}{ Total protein, $\%$} & 30 & 17.35 & $\pm 0.27^{\mathrm{ab}, \mathrm{A}}$ & $17.55 \pm 0.27^{\mathrm{a}, \mathrm{A}}$ & $16.84 \pm 0.00^{\mathrm{b}, \mathrm{C}}$ & $17.48 \pm 0.14^{\mathrm{a}, \mathrm{C}}$ \\
\hline & 60 & 17.22 & $\pm 0.23^{\mathrm{a}, \mathrm{A}}$ & $17.35 \pm 0.77^{\mathrm{a}, \mathrm{A}}$ & $18.06 \pm 0.23^{\mathrm{a}, \mathrm{B}}$ & $19.46 \pm 0.32^{\mathrm{b}, \mathrm{B}}$ \\
\hline & 90 & 17.16 & $\pm 0.45^{\mathrm{b}, \mathrm{A}}$ & $17.10 \pm 0.32^{\mathrm{b}, \mathrm{A}}$ & $19.46 \pm 0.23^{\mathrm{a}, \mathrm{A}}$ & $19.97 \pm 0.05^{\mathrm{a}, \mathrm{B}}$ \\
\hline & 120 & 16.65 & $\pm 0.23^{\mathrm{c}, \mathrm{A}}$ & $16.71 \pm 0.09^{\mathrm{c}, \mathrm{A}}$ & $19.78 \pm 0.50^{\mathrm{b}, \mathrm{A}}$ & $21.31 \pm 0.14^{\mathrm{a}, \mathrm{A}}$ \\
\hline
\end{tabular}

${ }^{\mathrm{a}-\mathrm{d}}$ Means \pm SD within a row with no common superscript differ $(P<0.05)$.

${ }^{\mathrm{A}-\mathrm{E}}$ Means $\pm \mathrm{SD}$ within a column with no common superscript differ $(P<0.05)$.

${ }^{1}$ Presented values are the means of 2 replicate trials. $\mathrm{P}$ and $\mathrm{T}$ refer to the cheeses ripened in plastic or tulum materials, respectively; 1 and 2 refer to the cheeses manufactured in dairies 1 and 2, respectively.

${ }^{2}$ Titratable acidity expressed as grams of lactic acid/100 grams of cheese.

Table 2. Microbiological characteristics (in log cfu/g) of Tulum cheeses ripened in plastic (P) or goat's skin bags $(\mathrm{T})$ during ripening ${ }^{1}$

\begin{tabular}{|c|c|c|c|c|c|}
\hline \multirow[b]{2}{*}{ Variable } & \multirow[b]{2}{*}{ Days } & \multicolumn{4}{|c|}{ Cheese } \\
\hline & & P1 & $\mathrm{P} 2$ & $\mathrm{~T} 1$ & $\mathrm{~T} 2$ \\
\hline \multirow[t]{5}{*}{ Total mesophilic bacteria } & 30 & $7.86 \pm 0.01^{\mathrm{a}, \mathrm{A}}$ & $7.47 \pm 0.10^{\mathrm{c}, \mathrm{A}}$ & $7.62 \pm 0.01^{\mathrm{b}, \mathrm{A}}$ & $7.30 \pm 0.03^{\mathrm{d}, \mathrm{A}}$ \\
\hline & 60 & $7.32 \pm 0.00^{\mathrm{a}, \mathrm{B}}$ & $7.04 \pm 0.04^{\mathrm{ab}, \mathrm{B}}$ & $6.30 \pm 0.04^{\mathrm{b}, \mathrm{C}}$ & $6.20 \pm 0.49^{\mathrm{b}, \mathrm{B}}$ \\
\hline & 90 & $6.84 \pm 0.01^{\mathrm{ab}, \mathrm{B}}$ & $6.89 \pm 0.02^{\mathrm{a}, \mathrm{B}}$ & $6.71 \pm 0.02^{\mathrm{b}, \mathrm{B}}$ & $6.20 \pm 0.12^{\mathrm{c}, \mathrm{B}}$ \\
\hline & 120 & $5.24 \pm 0.34^{\mathrm{b}, \mathrm{C}}$ & $6.15 \pm 0.05^{\mathrm{a}, \mathrm{C}}$ & $5.00 \pm 0.00^{\mathrm{b}, \mathrm{D}}$ & $4.94 \pm 0.00^{\mathrm{b}, \mathrm{C}}$ \\
\hline & 150 & $6.74 \pm 0.02^{\mathrm{a}, \mathrm{C}}$ & $6.65 \pm 0.07^{\mathrm{a}, \mathrm{D}}$ & $6.48 \pm 0.00^{\mathrm{a}, \mathrm{D}}$ & $6.15 \pm 0.21^{\mathrm{b}, \mathrm{C}}$ \\
\hline \multirow[t]{5}{*}{ Coliforms } & 30 & $4.92 \pm 0.03^{\mathrm{b}, \mathrm{A}}$ & $5.00 \pm 0.01^{\mathrm{b}, \mathrm{A}}$ & $4.28 \pm 0.06^{\mathrm{c}, \mathrm{A}}$ & $5.15 \pm 0.01^{\mathrm{a}, \mathrm{A}}$ \\
\hline & 60 & $4.72 \pm 0.01^{\mathrm{a}, \mathrm{B}}$ & $4.18 \pm 0.61^{\mathrm{a}, \mathrm{A}}$ & $3.59 \pm 0.02^{\mathrm{a}, \mathrm{B}}$ & $4.11 \pm 0.07^{\mathrm{a}, \mathrm{C}}$ \\
\hline & 90 & $3.87 \pm 0.04^{\mathrm{c}, \mathrm{C}}$ & $4.94 \pm 0.01^{\mathrm{a}, \mathrm{A}}$ & $3.88 \pm 0.04^{\mathrm{c}, \mathrm{C}}$ & $4.30 \pm 0.01^{\mathrm{b}, \mathrm{B}}$ \\
\hline & 120 & $3.60 \pm 0.08^{\mathrm{b}, \mathrm{D}}$ & $4.70 \pm 0.01^{\mathrm{a}, \mathrm{A}}$ & $2.48 \pm 0.02^{\mathrm{c}, \mathrm{D}}$ & $<1$ \\
\hline & 150 & $3.59 \pm 0.01$ & $<1$ & $<1$ & $<1$ \\
\hline \multirow[t]{5}{*}{ Yeasts and molds } & 30 & $6.04 \pm 0.06^{\mathrm{a}, \mathrm{C}}$ & $5.36 \pm 0.51^{\mathrm{ab}, \mathrm{D}}$ & $5.20 \pm 0.01^{\mathrm{b}, \mathrm{C}}$ & $5.67 \pm 0.01^{\mathrm{ab}, \mathrm{C}}$ \\
\hline & 60 & $6.78 \pm 0.07^{\mathrm{a}, \mathrm{B}}$ & $5.90 \pm 0.01^{\mathrm{b}, \mathrm{C}}$ & $5.44 \pm 0.02^{\mathrm{c}, \mathrm{B}}$ & $5.75 \pm 0.02^{\mathrm{b}, \mathrm{C}}$ \\
\hline & 90 & $6.79 \pm 0.01^{\mathrm{b}, \mathrm{B}}$ & $6.54 \pm 0.08^{\mathrm{c}, \mathrm{B}}$ & $5.79 \pm 0.02^{\mathrm{d}, \mathrm{A}}$ & $6.95 \pm 0.01^{\mathrm{a}, \mathrm{B}}$ \\
\hline & 120 & $4.34 \pm 0.01^{\mathrm{c}, \mathrm{D}}$ & $4.47 \pm 0.06^{\mathrm{c}, \mathrm{E}}$ & $4.76 \pm 0.04^{\mathrm{b}, \mathrm{D}}$ & $5.65 \pm 0.07^{\mathrm{a}, \mathrm{D}}$ \\
\hline & 150 & $7.57 \pm 0.01^{\mathrm{a}, \mathrm{A}}$ & $6.82 \pm 0.03^{\mathrm{d}, \mathrm{A}}$ & $7.12 \pm 0.05^{\mathrm{c}, \mathrm{E}}$ & $7.36 \pm 0.11^{\mathrm{b}, \mathrm{A}}$ \\
\hline
\end{tabular}

${ }^{\mathrm{a}-\mathrm{d}}$ Means $\pm \mathrm{SD}$ within a row with no common superscript differ $(P<0.05)$.

${ }^{\text {A-E }}$ Means \pm SD within a column with no common superscript differ $(P<0.05)$.

${ }^{1}$ Presented values are the means of 2 replicate trials. $\mathrm{P}$ and $\mathrm{T}$ refer to the cheeses ripened in plastic or tulum materials, respectively; 1 and 2 refer to the cheeses manufactured in dairies 1 and 2 , respectively. 
produced in dairy 2 than those in dairy $1(P<0.05)$. Their numbers decreased during ripening and reached less than $1 \mathrm{log} \mathrm{cfu} / \mathrm{g}$ cheese except in the P1 cheese at $150 \mathrm{~d}$. The growth of nonstarter lactic acid bacteria (NSLAB) and molds in cheese suppresses the growth of coliforms, which are also inhibited by the $\mathrm{pH}$ of cheeses. In addition, the lower coliform and total mesophilic bacterial counts in the cheeses ripened in tulums can be attributed to the lower moisture and higher saltin-moisture contents of the cheeses. Statistical differences were seen between all $\mathrm{T}$ and $\mathrm{P}$ cheeses, with the numbers of coliforms in $\mathrm{T}$ cheeses being lower than those of $\mathrm{P}$ cheeses during ripening $(P<0.05)$. In general, the coliform counts are high in Tulum cheese compared with other varieties, probably because raw milk is used in manufacturing the cheese and also because these bacteria might originate from handling, the production devices used, the environment, or the home-made coagulant. Other researchers found coliforms in Tulum cheese at levels of 4.04 (Kilic and Gonc, 1992), 6.51 (Kurt et al., 1991b), 3.23 (Oner et al., 2003), and 6.99 $\log \mathrm{cfu} / \mathrm{g}$ (Patir et al., 2000). Public opinion is that the coliforms disappear in Tulum cheese after $90 \mathrm{~d}$ of ripening. Indeed, the numbers of coliforms steadily decreased during ripening of the cheeses and disappeared after $150 \mathrm{~d}$ of ripening (Table 2).

The growth of molds is believed to be common and normal during the ripening of Tulum cheese, and the cheese is thought to be sufficiently ripened when mold becomes visible. The regulation for Tulum cheeses in Turkish standards (Turk Standartlari Enstitusu, 1995) allows up to $2 \mathrm{log} \mathrm{cfu} / \mathrm{g}$ of yeasts and molds. The numbers of yeasts and molds ranged from 5.20 to $6.04 \mathrm{log}$ $\mathrm{cfu} / \mathrm{g}$ at the first stage of ripening. Variations in the growth of yeasts and molds in Tulum cheeses were observed during ripening, and they reached the highest numbers at the last stage of ripening. The results for yeasts and molds in Tulum cheeses were similar to those found by Guven and Konar (1994a), Sengul et al. (2001), and Patir et al. (2001). The numbers of yeasts and molds were significantly affected by ripening in tulums or in plastic $(P<0.05)$. The growth of yeasts and molds cannot be prevented by the use of pasteurized milk, because the cheese mass is continuously in contact with air. Sengul et al. (2001) manufactured cheese from both pasteurized and raw milk, and they isolated these organisms from both cheeses at each stage of ripening. The authors also reported that the counts of yeasts and molds in cheeses ripened in tulums were significantly higher than those of cheeses ripened in plastic. Similar results were observed in the present study, probably because of the permeability of the tulum to air.

\section{Nitrogen Fractions}

The concentrations of WSN, TCA-SN, and PTA-SN as a percentage of TN increased significantly during ripening (data not shown). The levels of WSN (\%TN) were essentially the same in all cheeses, and the production of cheeses in different dairies and ripened in different packaging materials had no significant effect on the WSN (\%TN) contents of the cheeses. Similarly, Guven and Konar (1994b) and Sengul and Cakmakci (1998) reported that ripening in tulums or plastic packaging materials did not influence the WSN (\%TN) content of Tulum cheeses. Differences in the levels of TCA-SN (\%TN) between the cheeses were significant during ripening $(P<0.05)$; however, these differences were not caused by the ripening container (tulum or plastic). The levels of PTA-SN (\%TN) increased significantly $(P<$ 0.05 ) and were higher (but not significant) in the T1 cheese than in other cheeses throughout ripening. The slight differences in nitrogen fractions can be linked to the lower moisture contents in the cheeses ripened in tulums.

\section{Total and Individual FAA}

The concentration of total FAA in cheeses gradually increased during ripening (Figure 1). The highest and lowest total FAA contents were found in T1 and P1 cheeses, respectively; the final value in the T2 cheese was $8.84 \mathrm{mg}$ of Leu/g at $120 \mathrm{~d}$. No significant differences were noted between cheeses at 60 or $90 \mathrm{~d}$ of ripening. A similar trend was observed for the level of total FAA as was observed for the nitrogen fractions. This can be attributed to the action of peptidases from the lactic acid bacteria in all cheeses. Some differences were seen between dairies at some stages of ripening. In addition, total FAA in the cheeses ripened in tulums were slightly higher (but not significant). This may be attributed to the lower moisture contents of the cheeses (see Table 1). The extent of proteolysis in Tulum cheeses was also monitored by determining the concentration of individual FAA at 30 and $120 \mathrm{~d}$ of ripening. The concentrations of the individual FAA in the cheeses increased with age, with the exception of Glu, Tyr, and Lys in the cheeses ripened in tulums. The cheeses ripened in tulums exhibited higher concentrations of the majority of the FAA (Figure 2) at each ripening time; however, concentrations of Asp, Ser, Glu, Tyr, His, and Lys were higher in the cheeses ripened in plastic than in the cheeses ripened in tulums. The total concentrations of individual FAA in these cheeses were higher in the cheeses ripened in tulums than in those ripened in plastic at $30 \mathrm{~d}(47.37$ and $82.86 \mathrm{mg} / 100 \mathrm{~g}$ in P1 and $\mathrm{T} 1$ cheeses, respectively), whereas their concentrations were similar at $120 \mathrm{~d}$ (125.29 and $133.46 \mathrm{mg} / 100 \mathrm{~g})$. 


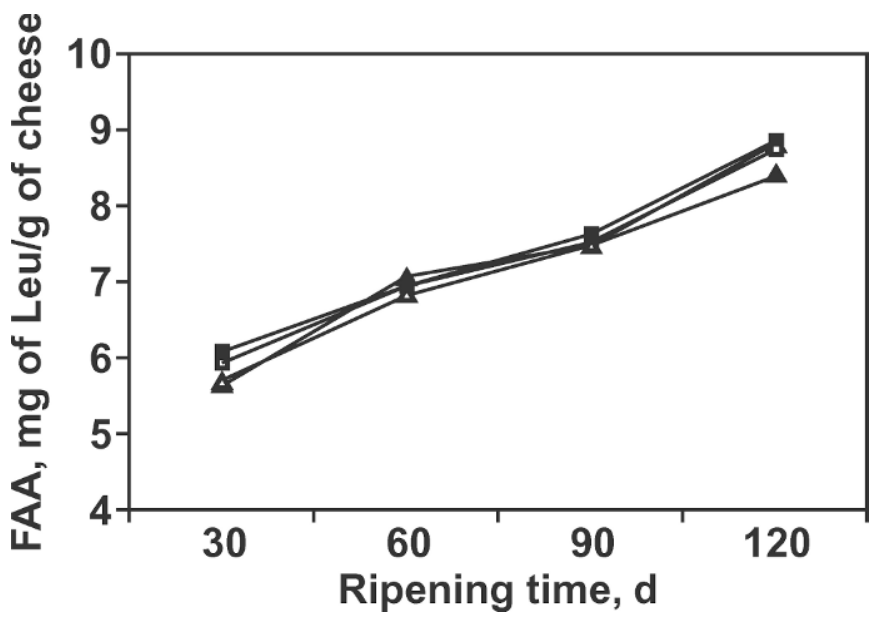

Figure 1. Formation of total free AA (FAA) during ripening of Tulum cheese ripened in plastic $(\mathrm{P} 1, \mathbf{\Delta} ; \mathrm{P} 2, \triangle)$ and goat's skin (T1, $\square ; \mathrm{T} 2, \square) . \mathrm{P}$ and $\mathrm{T}$ refer to the cheeses ripened in plastic or tulum materials, respectively; 1 and 2 refer to the cheeses manufactured in dairies 1 and 2 , respectively.

The principal FAA in the cheeses were Glu, Ala, Val, Leu, and Phe at 30 or $120 \mathrm{~d}$ of ripening. Guven (1993) also reported that Glu and Leu were the most abundant FAA in Tulum cheeses made from ewe's milk.

\section{Urea-PAGE}

Urea-PAGE electrophoretograms of the $\mathrm{pH}$ 4.6-insoluble fractions of the cheeses during ripening are shown in Figure 3. Similar degradation patterns were observed in all cheeses during ripening; the effect of different ripening containers or dairies was not significant. No significant differences were found in the patterns of CN hydrolysis. This was an expected result because of the fact that coagulant and plasmin are primarily responsible for the proteolysis detectable by PAGE (Visser, 1977; Fox et al., 1996). $\beta$-Casein underwent slight proteolysis during $120 \mathrm{~d}$ of ripening, and the intensities of the bands of $\beta$-CN were slightly different from those of the young cheeses. Most of the $\beta$-CN remained intact at the end of the ripening period, indicating that $\beta-\mathrm{CN}$ was resistant to proteolysis. To the authors' knowledge, the gel electrophoretic pattern of Tulum cheese has not been reported previously. There was no difference between $\mathrm{T}$ and $\mathrm{P}$ cheeses with respect to the degradation of intact $\alpha_{\mathrm{s} 1}-\mathrm{CN}$. After $120 \mathrm{~d}$ of ripening, $\alpha_{\mathrm{s} 1}-\mathrm{CN}$ was hydrolyzed but not completely. Some weak bands with faster electrophoretic mobility than $\alpha_{\mathrm{s} 1}$-CN appeared on the gel.

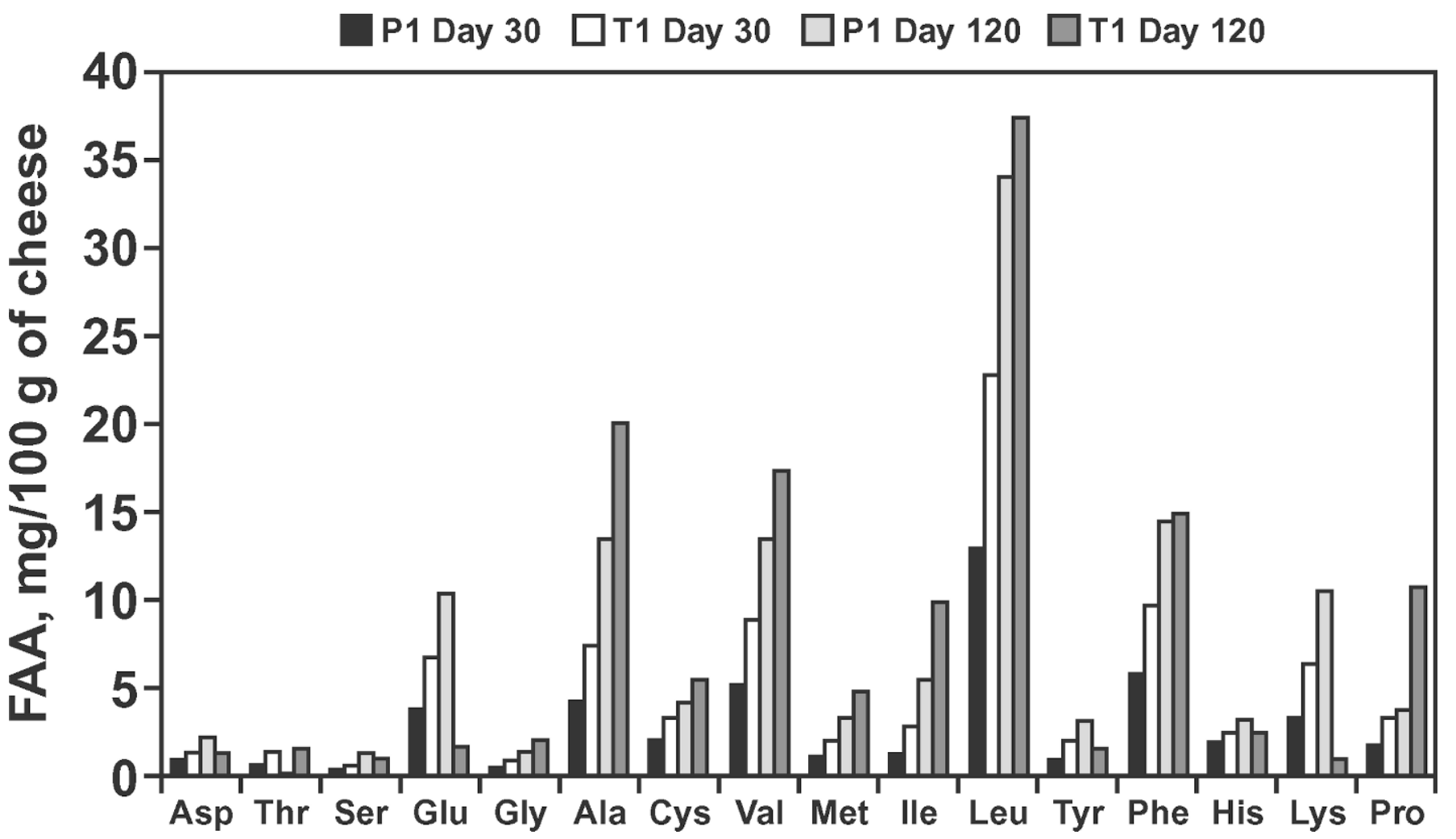

Figure 2. Individual free AA (FAA) concentrations at 30 and $120 \mathrm{~d}$ in Tulum cheese ripened in plastic or goat's skin bags. $\mathrm{P}$ and $\mathrm{T}$ refer to the cheeses ripened in plastic or tulum materials, respectively; 1 refers to the cheeses manufactured in dairy 1 . 


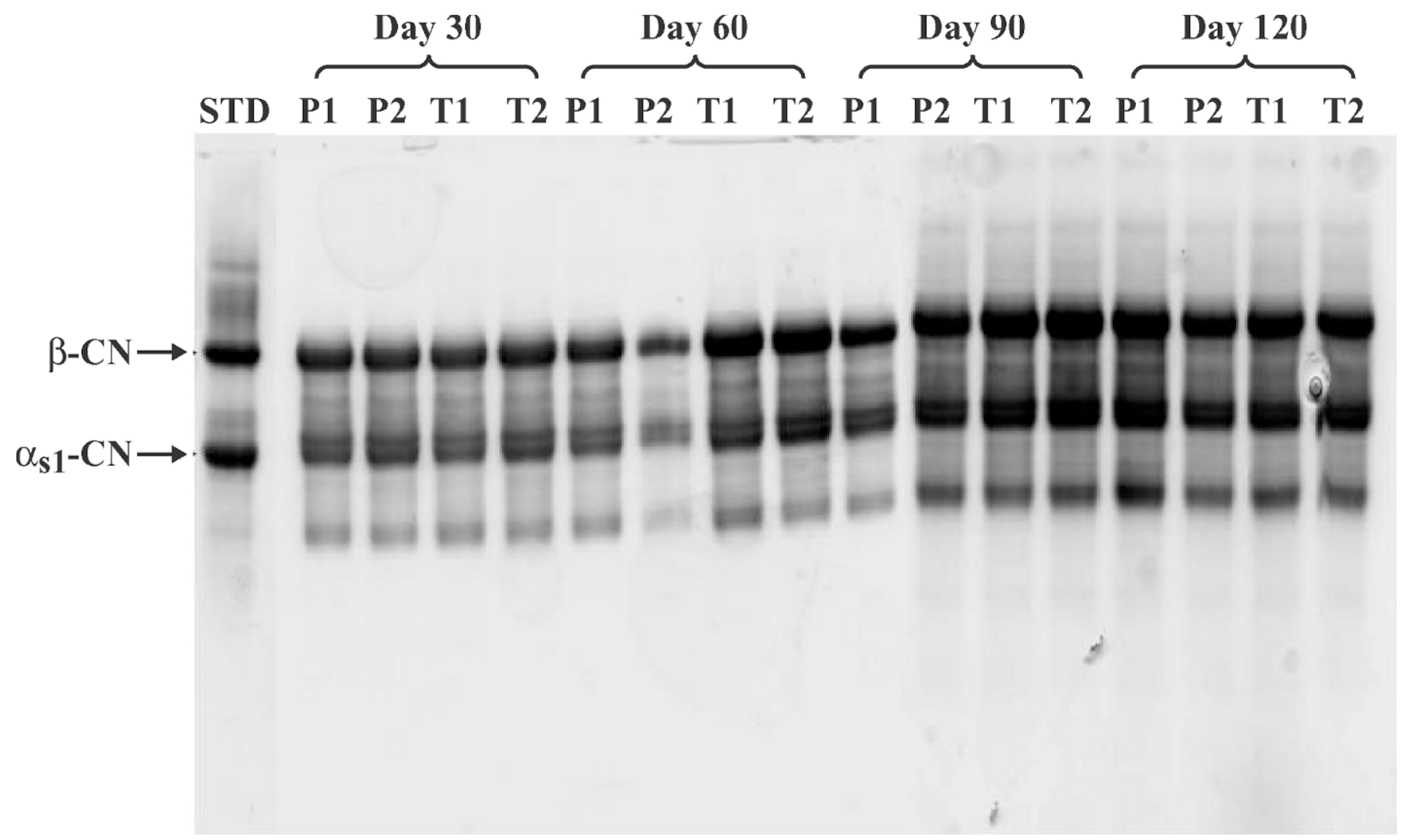

Figure 3. Urea-PAGE electrophoretograms of the pH 4.6-insoluble fractions of Tulum cheeses ripened in plastic or goat's skin bags after ripening for $30,60,90$, and $120 \mathrm{~d}$. STD = sodium caseinate; $\mathrm{P}$ and T refer to the cheeses ripened in plastic or tulum materials, respectively; 1 and 2 refer to the cheeses manufactured in dairies 1 and 2 , respectively.

\section{RP-HPLC}

To characterize the proteolytic profile of Tulum cheese in detail, the cheese was extracted at $\mathrm{pH} 4.6$ and then subfractionated with ethanol $70 \%$ ( $\mathrm{vol} / \mathrm{vol}$ ) into ethanol-soluble (EtOH-s) and ethanol-insoluble (EtOH-i) fractions. The peptide profiles of these extracts were determined by RP-HPLC, and elution was monitored at $214 \mathrm{~nm}$.

pH 4.6-Soluble Fraction. The RP-HPLC profiles of the $\mathrm{pH} 4.6$-soluble fractions of Tulum cheeses during $120 \mathrm{~d}$ of ripening are shown in Figure 4. The chromatograms indicated that some qualitative differences were found between the $\mathrm{T}$ and $\mathrm{P}$ cheeses. At $30 \mathrm{~d}$ of ripening, all cheeses showed essentially similar peaks except the $\mathrm{T} 2$ cheese, which had different concentrations of peptides eluting, with retention times of 45 to $50 \mathrm{~min}$. Some peaks in the cheeses were different in height (e.g., 12, $16,18,22$ to 24 , and 41). Peak 42 was not present in the T2 cheese or its concentration was very low. The peptide profiles of the cheeses showed the same trend, with minor differences at $60 \mathrm{~d}$ of ripening; however, as ripening proceeded, the peptide patterns of the cheeses changed and some new peptides were eluted in the intermediate region (from 30 to $50 \mathrm{~min}$ ). On the other hand, some peptides (numbered 51 to 55) or those eluting in the hydrophobic region (50 to $70 \mathrm{~min}$ ) disappeared after $90 \mathrm{~d}$ of ripening, presumably because of hydrolysis of the $\mathrm{pH} 4.6$-soluble peptides to FAA or shorter peptides. The breakdown of these peptides can be explained by the action of enzymes released from lysed lactic acid bacterial cells (El-Soda et al., 1995; Urbach, 1995). Hannon et al. (2003) reported that the peak heights decreased during 8 mo of ripening in Cheddar cheese made with lactobacilli because of the action of peptidases from adjunct lactobacilli. The continual degradation of the large peptides into smaller peptides and AA has an effect by decreasing the areas or heights of the peaks (Fox et al., 1996).

70\% (vol/vol) EtOH-s Fraction. The lyophilized EtOH-s fractions of the 30- or 120-d-old cheeses were also analyzed by RP-HPLC. The chromatograms of the EtOH-s fractions of the cheeses showed that some major peptides were similar in all cheeses (Figure 5). For example, on $d 30$, the peaks numbered $7,15,24,25,31$, 31 , and 35 were present in all cheeses. However, some 


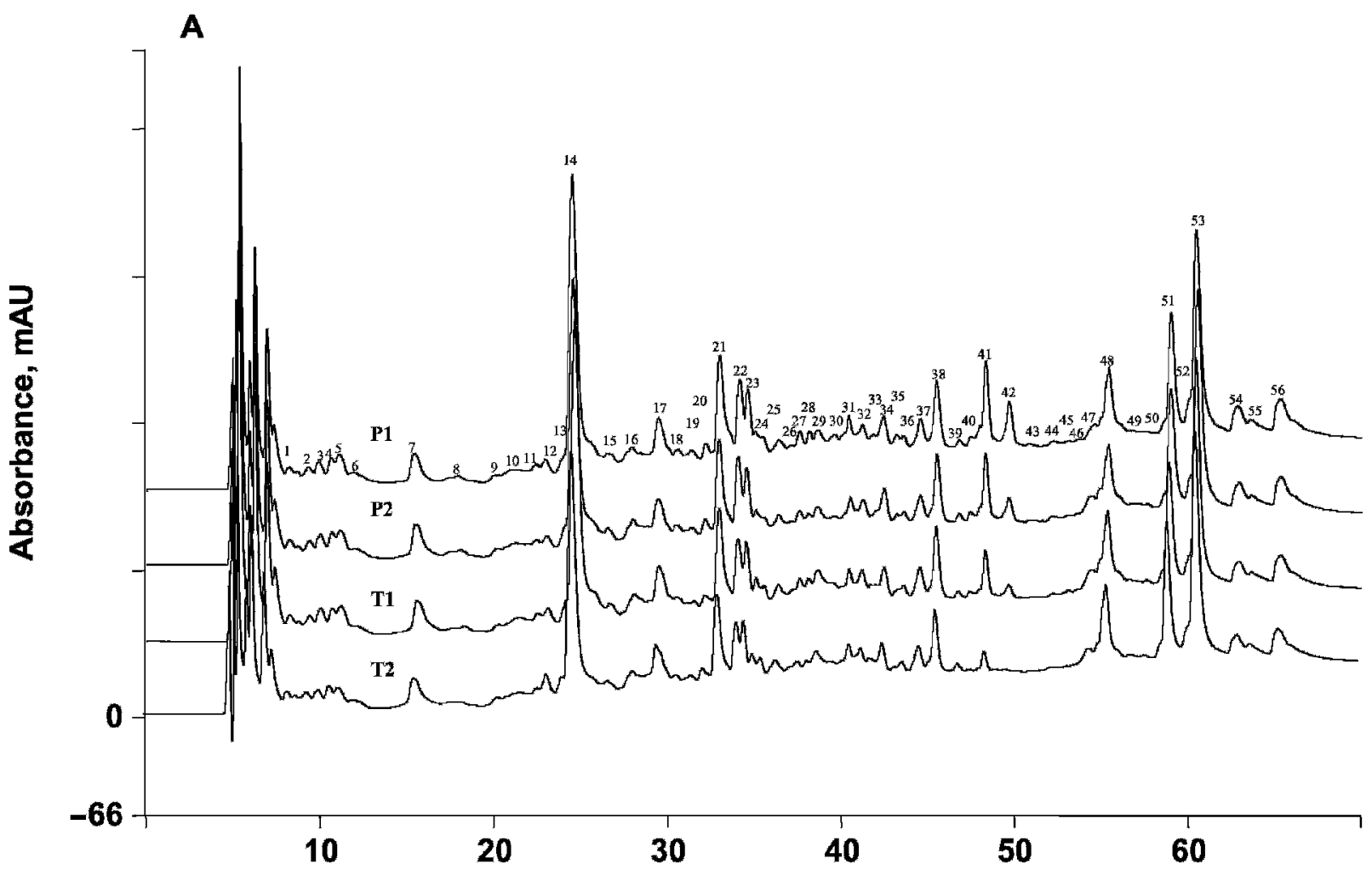

B

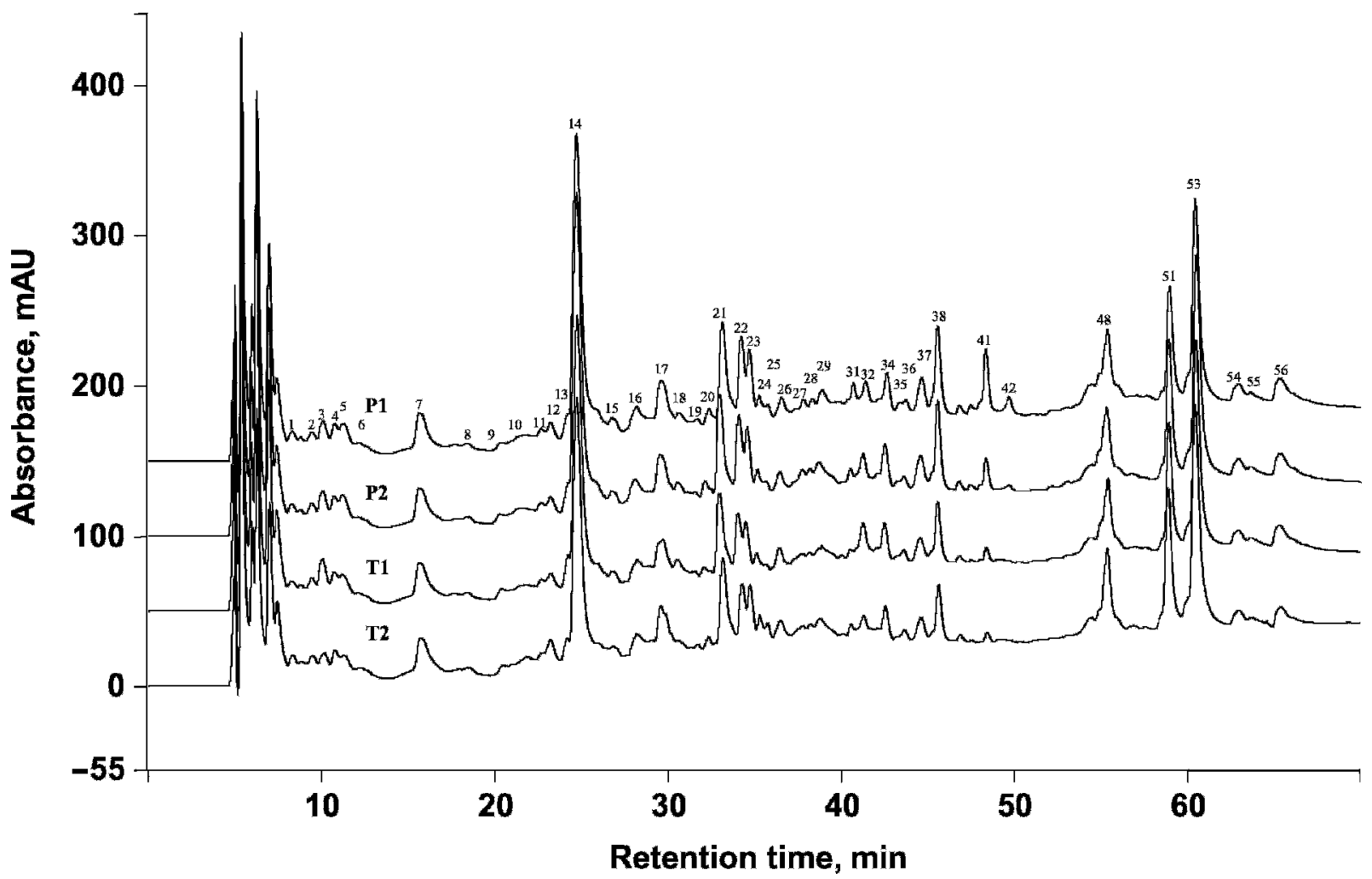

Figure 4. Reversed phase-HPLC peptide profiles of the $\mathrm{pH}$ 4.6-soluble fractions from Tulum cheeses ripened in plastic or goat's skin bags after 30 (A), 60 (B), 90 (C), and $120 \mathrm{~d}$ (D) of ripening. P and T refer to the cheeses ripened in plastic or tulum materials, respectively; 1 and 2 refer to the cheeses manufactured in dairies 1 and 2, respectively. $\mathrm{AU}=$ absorbance units. 

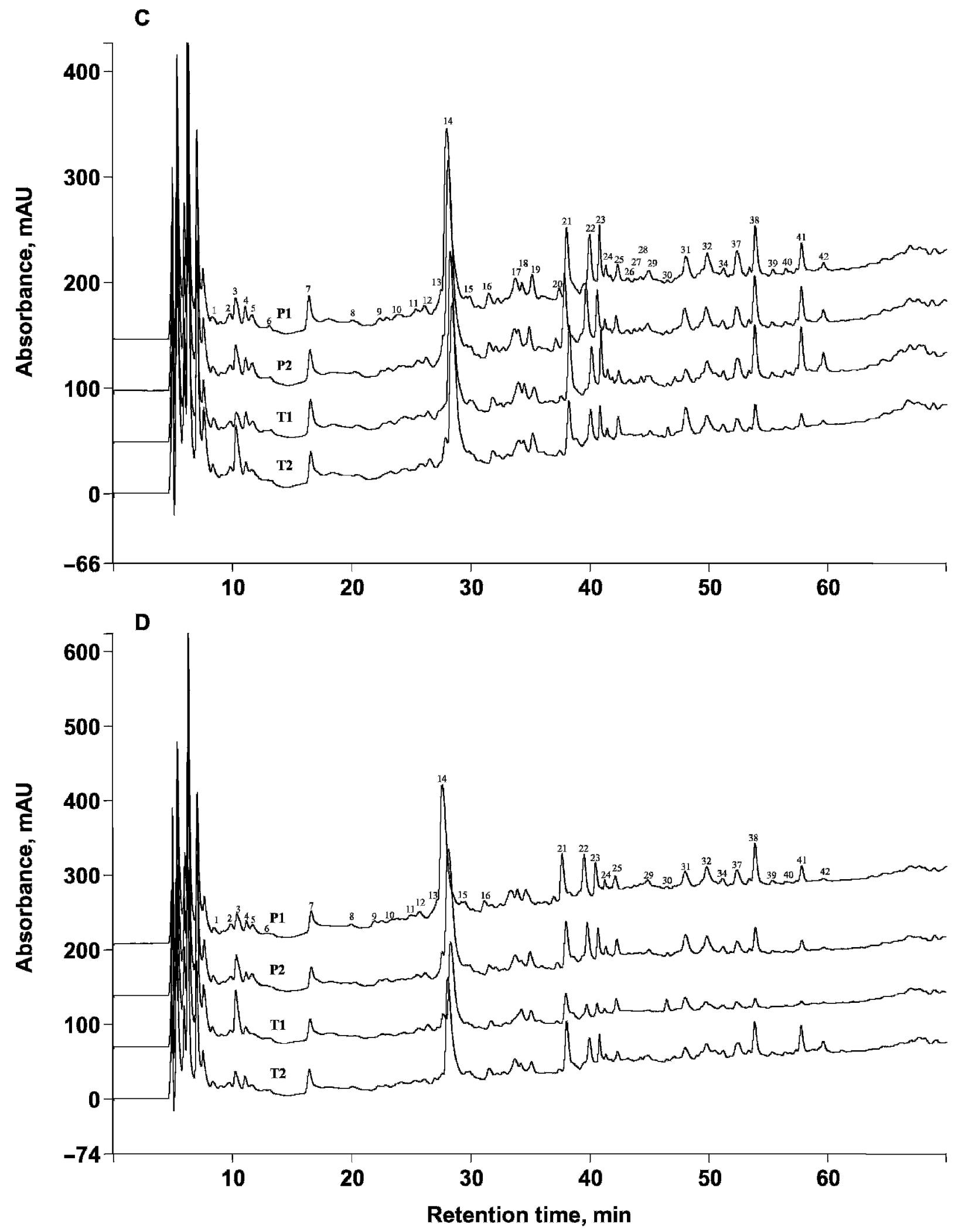

Figure 4 (Continued). Reversed phase-HPLC peptide profiles of the $\mathrm{pH} 4.6$-soluble fractions from Tulum cheeses ripened in plastic or goat's skin bags after 30 (A), 60 (B), 90 (C), and $120 \mathrm{~d}$ (D) of ripening. P and T refer to the cheeses ripened in plastic or tulum materials, respectively; 1 and 2 refer to the cheeses manufactured in dairies 1 and 2, respectively. $\mathrm{AU}=$ absorbance units. 
peaks, including $3,19,20,25,31,33,36,38,39$, and 43 to 45 , were present at different levels. The relatively large early-eluting peaks contained AA or hydrophilic peptides. After $120 \mathrm{~d}$ of ripening, no significant differences were noted in peaks eluting at short retention times; however, the concentrations of the peaks eluting in the later region (50 to $70 \mathrm{~min}$ ) decreased because of hydrolysis of the peptides.

70\% (vol/vol) EtOH-i Fraction. Peptide profiles of the EtOH-i fractions of the 30- or 120-d-old cheeses by RP-HPLC are shown in Figure 6. The chromatograms of the EtOH-i fraction indicated that some peptides present at high concentrations eluted at the end of the hydrophobic region of the chromatogram. Most of the late-eluting peptides are hydrophobic (Sousa and McSweeney, 2001). In general, ripening in either tulum or plastic packaging material did not noticeably alter the peptide profiles; however, some peaks eluted at lower concentrations in the $\mathrm{T} 1$ and $\mathrm{T} 2$ cheeses than in the $\mathrm{P} 1$ and $\mathrm{P} 2$ cheeses at 30 or $120 \mathrm{~d}$ of ripening. Interestingly, some of the peptides present at higher concentrations in the cheeses eluted in the hydrophobic region (60 to $70 \mathrm{~min}$ ). The corresponding peptides were hydrolyzed extensively after $120 \mathrm{~d}$ of ripening, probably because of proteolytic enzymes from the lactic flora (Lau et al., 1991; Lee et al., 1996; Gomez et al., 1997).

\section{Volatile Composition}

The transformed [SQRT (area $\left.\left./ 10^{5}\right)\right]$ mean concentrations of volatile compounds identified by solid-phase microextraction of the Tulum cheeses are shown in Tables 3 to 10 . In total, 100 volatile compounds were identified from the cheeses. The volatiles include 11 acids (Table 3), 16 esters (Table 4), 12 methyl ketones (Table 5), 7 aldehydes (Table 6), 22 alcohols (Table 7 ), 7 sulfur compounds (Table 8), 6 terpenes (Table 9), and 19 miscellaneous compounds (Table 10). The profile of volatile aroma compounds in this cheese had not previously been studied by other researchers; however, many of these components, which are responsible for the typical aroma associated with a particular type of cheese, have already been reported in other varieties.

Acids. Most of the acids present in the cheeses originated from lipolysis of the milk fat (Urbach, 1997). Ethanoic, propanoic, and butanoic acids are produced by lipolysis or the fermentation of lactose or lactic acid; however, 2-methyl propanoic, 2-methyl butanoic, and 3 -methyl butanoic acids are produced by the metabolism of the AA Val, Leu, and Ile, respectively (Molimard and Spinnler, 1996; Urbach, 1997). The concentrations of short-chain fatty acids measured in the headspace of the cheeses were higher than those of medium-chain acids. Significant differences in the concentrations of 2-methyl propanoic, 2-methyl butanoic, and 3-methyl butanoic acids were found among cheese samples (Table 3 ). The P1 cheeses contained the highest concentrations of these acids. The principal acids in Tulum cheeses were ethanoic and butanoic acids (Table 3). Yilmaz et al. (2005) reported that the dominant volatile FA in Tulum cheese was butanoic acid. In addition to by the fermentation of lactose, ethanoic acid is also formed from the oxidation of lactate by the action of NSLAB or catabolism of the AA Ala or Ser by starter bacteria or NSLAB (Shakeel-Ur-Rehman et al., 2000a). Butanoic acid is produced mainly by lipolysis (McSweeney and Sousa, 2000), and other pathways in the production of butanoic acid in cheese are through catabolism of some AA such as Val, Thr, Glu, and Met (Bosset et al., 1993). Propanoic and 2-methyl propanoic acids were found at the highest and lowest concentrations in the $\mathrm{P} 1$ and $\mathrm{T} 1$ cheeses, respectively. Benzoic acid was also found in all experimental cheeses, and no differences were encountered among the cheeses. Urbach (1997) reported that this acid is found in cheese and is formed by the enzyme-mediated breakdown of hippuric acid or the AA Phe.

Esters. Esters, which are responsible for the fruity flavor in cheese, are formed through 2 enzymatic reactions, esterification and alcoholysis. Esterification is the formation of esters from alcohols and carboxylic acids, whereas alcoholysis is the production of esters from alcohols and acylglycerols or from alcohols or acyl-coenzyme A (Liu et al., 2004). Table 4 shows the mean concentrations of esters identified in Tulum cheeses at $90 \mathrm{~d}$ of ripening. A total of 16 esters [i.e., ethyl (9), propyl (4), and butyl (3) esters] were identified in Tulum cheeses, and most were ethyl esters. The ethyl esters were also the main esters found in Idiazabal (Barron et al., 2005), Grana Padano (Moio and Addeo, 1998), Minas (Correa Lelles Nogueira et al., 2005), and Roncal (Ortigosa et al., 2005) cheeses. The concentrations of ethyl acetate, ethyl butanoate, ethyl lactate, propyl acetate, and 3-methylbutyl acetate were high and were the principal volatile compounds in the cheeses. Ethyl 2-hydroxy 4-methyl pentanoate and 3-methylbutyl lactate were not identified in the $\mathrm{P} 1$ cheese. The concentrations of ethyl butanoate, ethyl hexanoate, ethyl lactate, and propyl acetate were highest in the $\mathrm{T} 1$ cheese and were significantly influenced by the different ripening containers. Higher concentrations of esters in the cheeses could be correlated with higher concentrations of alcohols in the cheeses because of esterification reactions between the fatty acids and alcohols (see Tables 3 and 7).

Methyl Ketones. Methyl ketones are the principal flavor compounds in Blue cheese and are formed by 

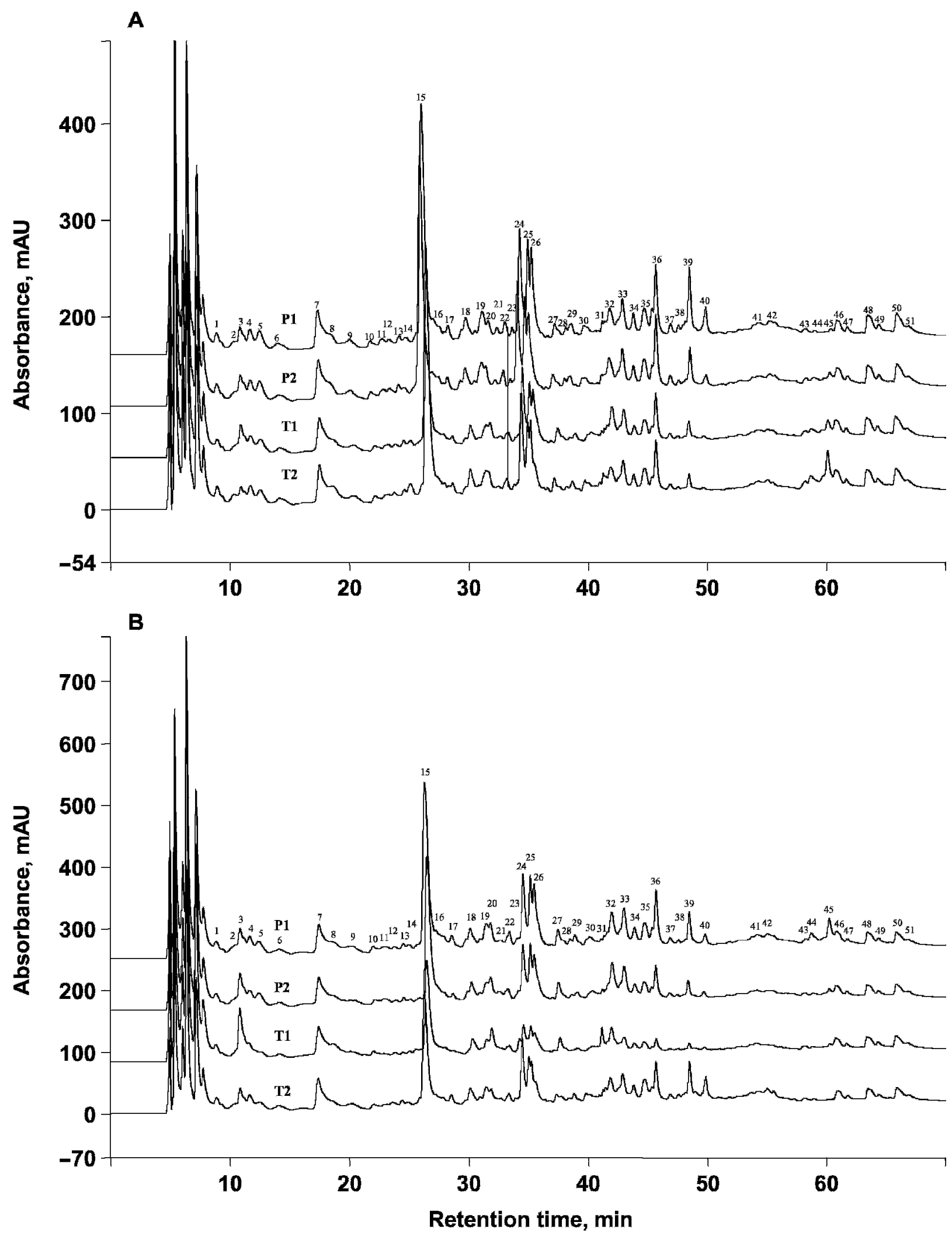

Figure 5. Reversed-phase HPLC peptide profiles of the $70 \%$ ethanol-soluble fractions from Tulum cheeses ripened in plastic or goat's skin bags after 30 (A) and $120 \mathrm{~d}$ (B) of ripening. P and T refer to the cheeses ripened in plastic or tulum materials, respectively; 1 and 2 refer to the cheeses manufactured in dairies 1 and 2, respectively. $\mathrm{AU}=$ absorbance units. 
A

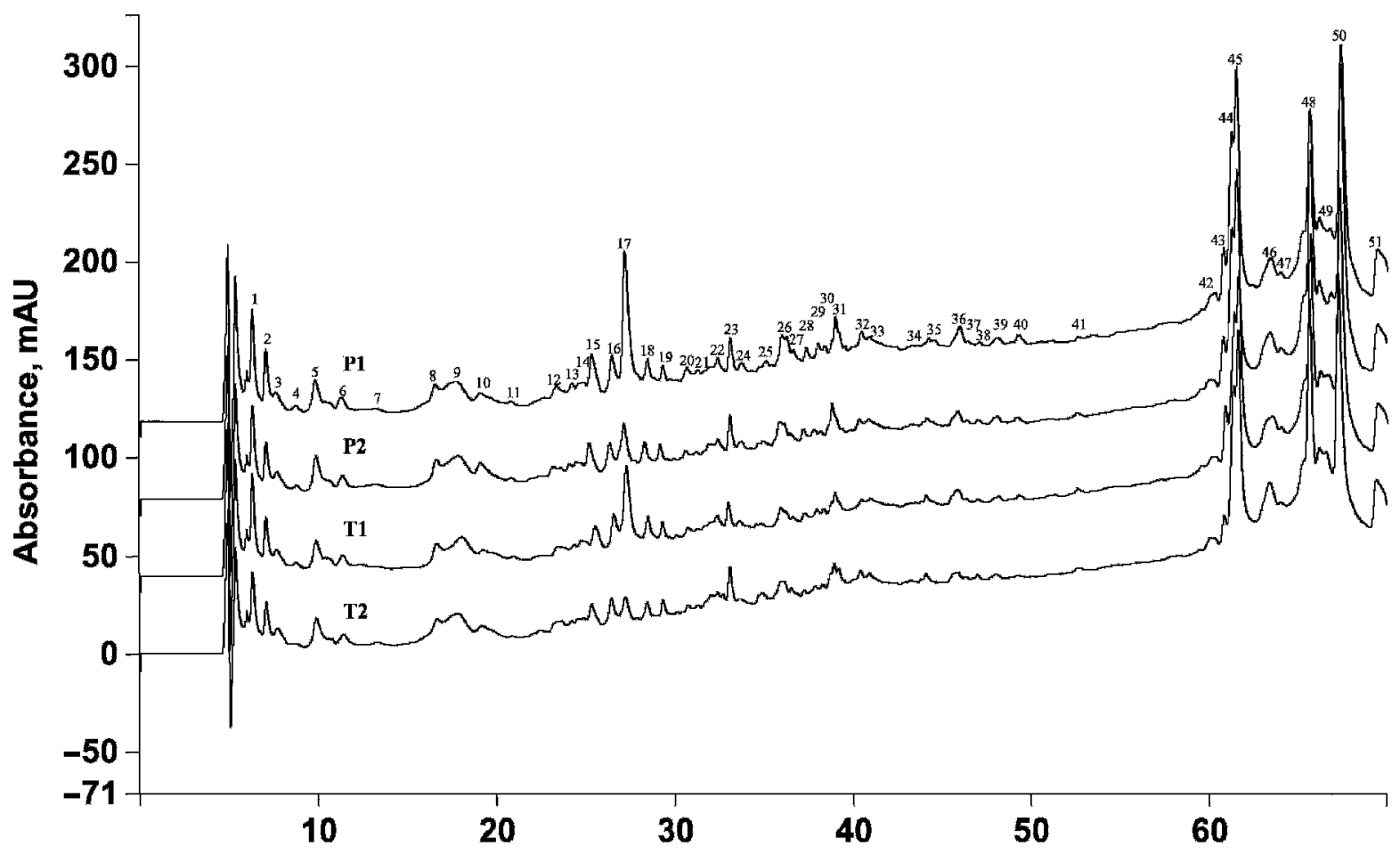

B

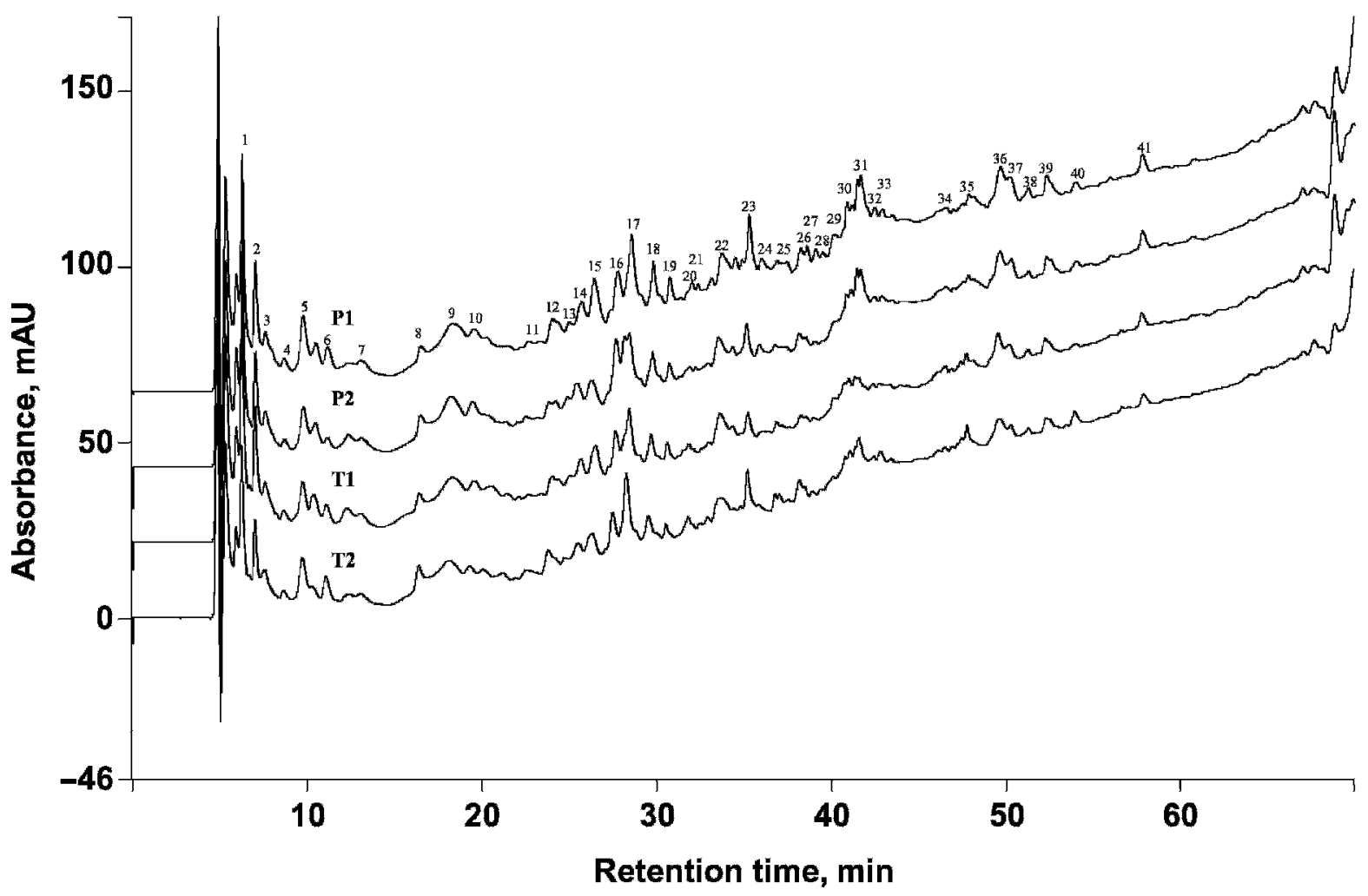

Figure 6. Reversed-phase HPLC peptide profiles of the 70\% ethanol-insoluble fractions from Tulum cheeses ripened in plastic or goat's skin bags after 30 (A) and $120 \mathrm{~d}$ (B) of ripening. $\mathrm{P}$ and $\mathrm{T}$ refer to the cheeses ripened in plastic or tulum materials, respectively; 1 and 2 refer to the cheeses manufactured in dairies 1 and 2, respectively. $\mathrm{AU}=$ absorbance units. 
Table 3. Concentrations of acids in 90-d-old Tulum cheeses ripened in plastic $(\mathrm{P})$ or goat's skin bags $(\mathrm{T})^{1}$

\begin{tabular}{lrrrr}
\hline & \multicolumn{4}{c}{ Cheese } \\
\cline { 2 - 5 } Acid & \multicolumn{1}{c}{$\mathrm{P} 1$} & \multicolumn{1}{c}{$\mathrm{P} 2$} & \multicolumn{1}{c}{$\mathrm{T} 1$} & \multicolumn{1}{c}{$\mathrm{T} 2$} \\
\hline Ethanoic acid & $17.51 \pm 4.78^{\mathrm{a}}$ & $30.74 \pm 0.32^{\mathrm{a}}$ & $29.55 \pm 1.22^{\mathrm{a}}$ & $24.36 \pm 3.19^{\mathrm{a}}$ \\
Propanoic acid & $17.41 \pm 1.37^{\mathrm{a}}$ & $16.18 \pm 0.22^{\mathrm{a}}$ & $12.88 \pm 0.87^{\mathrm{a}}$ & $17.28 \pm 0.77^{\mathrm{a}}$ \\
2-Methyl propanoic acid & $25.24 \pm 0.96^{\mathrm{a}}$ & $17.84 \pm 0.39^{\mathrm{b}}$ & $3.27 \pm 0.31^{\mathrm{c}}$ & $17.95 \pm 0.76^{\mathrm{b}}$ \\
Butanoic acid & $28.75 \pm 1.68^{\mathrm{a}}$ & $31.34 \pm 0.52^{\mathrm{a}}$ & $34.55 \pm 1.51^{\mathrm{a}}$ & $29.78 \pm 0.58^{\mathrm{a}}$ \\
2-Methyl butanoic acid & $12.32 \pm 0.28^{\mathrm{a}}$ & $8.34 \pm 0.24^{\mathrm{b}}$ & $1.69 \pm 0.25^{\mathrm{c}}$ & $8.70 \pm 0.50^{\mathrm{b}}$ \\
3-Methyl butanoic acid & $24.40 \pm 0.44^{\mathrm{a}}$ & $15.48 \pm 0.40^{\mathrm{b}}$ & $3.46 \pm 0.51^{\mathrm{c}}$ & $17.20 \pm 0.94^{\mathrm{b}}$ \\
Pentanoic acid & $2.93 \pm 0.18^{\mathrm{a}}$ & $3.19 \pm 0.14^{\mathrm{a}}$ & $3.50 \pm 0.34^{\mathrm{a}}$ & $3.05 \pm 0.08^{\mathrm{a}}$ \\
Hexanoic acid & $15.85 \pm 0.48^{\mathrm{a}}$ & $21.46 \pm 0.15^{\mathrm{a}}$ & $23.50 \pm 1.36^{\mathrm{a}}$ & $19.24 \pm 0.81^{\mathrm{a}}$ \\
Octanoic acid & $4.87 \pm 0.23^{\mathrm{a}}$ & $7.63 \pm 0.28^{\mathrm{a}}$ & $8.66 \pm 1.12^{\mathrm{a}}$ & $7.96 \pm 0.18^{\mathrm{a}}$ \\
Decanoic acid & $1.85 \pm 0.12^{\mathrm{a}}$ & $2.44 \pm 0.09^{\mathrm{a}}$ & $2.63 \pm 0.26^{\mathrm{a}}$ & $2.44 \pm 0.08^{\mathrm{a}}$ \\
Benzoic acid & $2.46 \pm 0.27^{\mathrm{a}}$ & $3.07 \pm 0.14^{\mathrm{a}}$ & $2.57 \pm 0.59^{\mathrm{a}}$ & $2.85 \pm 0.11^{\mathrm{a}}$ \\
Total & $153.58 \pm 0.98$ & $157.71 \pm 0.26$ & $126.26 \pm 0.76$ & $150.80 \pm 0.73$ \\
\hline
\end{tabular}

${ }^{\mathrm{a}-\mathrm{c}}$ Means $\pm \mathrm{SD}$ within a row with no common superscript differ $(P<0.01)$.

${ }^{1}$ Results are expressed as square roots $\left(\right.$ area $/ 10^{5}$ ) from a triplicate analysis of each cheese. $\mathrm{P}$ and $\mathrm{T}$ refer to the cheeses ripened in plastic or tulum materials, respectively; 1 and 2 refer to the cheeses manufactured in dairies 1 and 2, respectively.

enzymatic oxidation of FFA to $\beta$-ketoacids and their consequent decarboxylation to methyl ketones (Engels et al., 1997; McSweeney and Sousa, 2000), which contribute to the pungent aroma of Blue cheese (Ortigosa et al., 2001). However, 2-butanone derives from diacetyl, which is produced by the metabolism of lactose or citrate. Table 5 shows the mean concentrations of methyl ketones; 2-butanone and diacetyl were the most abundant ketones in Tulum cheeses, suggesting the action of citrate-utilizing bacteria. The concentration of methyl ketones, including 2-propanone, 2-pentanone, 2-hexanone, 3-hydroxy 2-pentanone, and diacetyl, were influenced by the packaging material. The highest concen- trations of 2-pentanone, 2-heptanone, 2-hydroxy 2-butanone (acetoin), 2-hexanone, and diacetyl were found in the T2 cheese, but 2-propanone and 2-butanone were high in the P1 cheese. 2-Pentanone and 2-hexanone were not determined in the T1 cheese. The P1 and T2 cheeses had higher concentrations of methyl ketones than the other cheeses, suggesting the role of yeasts and molds in the formation of methyl ketones in the cheeses (Correa Lelles Nogueira et al., 2005). The counts of yeasts and molds were higher in these cheeses during most of the ripening period. According to trained panelists used to assess Tulum cheeses, the perception of a pungent aroma demonstrates the maturity of the

Table 4. Concentrations of esters in 90-d-old Tulum cheeses ripened in plastic (P) or goat's skin bags $(\mathrm{T})^{1}$

\begin{tabular}{lrrrr}
\hline & \multicolumn{4}{c}{ Cheese } \\
\cline { 2 - 5 } Ester & \multicolumn{1}{c}{$\mathrm{P} 1$} & \multicolumn{1}{c}{$\mathrm{P} 2$} & \multicolumn{1}{c}{$\mathrm{T} 1$} & \multicolumn{1}{c}{$\mathrm{T} 2$} \\
\hline Ethyl acetate & $3.90 \pm 0.22^{\mathrm{b}}$ & $22.29 \pm 0.32^{\mathrm{a}}$ & $20.55 \pm 0.84^{\mathrm{a}}$ & $3.55 \pm 0.21^{\mathrm{b}}$ \\
Ethyl propanoate & $1.10 \pm 0.03^{\mathrm{b}}$ & $6.40 \pm 0.04^{\mathrm{a}}$ & $6.83 \pm 0.40^{\mathrm{a}}$ & $1.79 \pm 0.32^{\mathrm{b}}$ \\
Ethyl butanoate & $6.81 \pm 0.16^{\mathrm{c}}$ & $16.10 \pm 0.26^{\mathrm{b}}$ & $21.55 \pm 1.36^{\mathrm{a}}$ & $7.77 \pm 0.68^{\mathrm{c}}$ \\
Ethyl hexanoate & $4.71 \pm 0.63^{\mathrm{a}}$ & $8.50 \pm 0.70^{\mathrm{a}}$ & $10.57 \pm 1.48^{\mathrm{a}}$ & $8.88 \pm 0.41^{\mathrm{a}}$ \\
Ethyl octanoate & $1.76 \pm 0.16^{\mathrm{b}}$ & $2.65 \pm 0.15^{\mathrm{ab}}$ & $3.46 \pm 0.36^{\mathrm{a}}$ & $3.12 \pm 0.07^{\mathrm{a}}$ \\
Ethyl decanoate & $1.06 \pm 0.09^{\mathrm{a}}$ & $1.42 \pm 0.14^{\mathrm{a}}$ & $1.64 \pm 0.12^{\mathrm{a}}$ & $1.44 \pm 0.04^{\mathrm{a}}$ \\
Ethyl lactate & $5.93 \pm 1.32^{\mathrm{c}}$ & $15.21 \pm 0.68^{\mathrm{b}}$ & $21.04 \pm 1.15^{\mathrm{a}}$ & $7.96 \pm 1.27^{\mathrm{c}}$ \\
Ethyl 2-hydroxy 4-methyl pentanoate & $\mathrm{ND}$ & $1.09 \pm 0.07^{\mathrm{a}}$ & $1.43 \pm 0.16^{\mathrm{a}}$ & $1.12 \pm 0.07^{\mathrm{a}}$ \\
1-Methylethyl lactate & $0.77 \pm 0.67^{\mathrm{c}}$ & $3.73 \pm 0.12^{\mathrm{b}}$ & $6.11 \pm 0.39^{\mathrm{a}}$ & $2.51 \pm 0.67^{\mathrm{b}}$ \\
Propyl acetate & $2.77 \pm 0.06^{\mathrm{c}}$ & $10.66 \pm 0.18^{\mathrm{b}}$ & $13.76 \pm 0.73^{\mathrm{a}}$ & $2.61 \pm 0.09^{\mathrm{c}}$ \\
Propyl hexanoate & $0.82 \pm 0.16^{\mathrm{a}}$ & $1.38 \pm 0.10^{\mathrm{a}}$ & $1.92 \pm 0.22^{\mathrm{a}}$ & $1.52 \pm 0.36^{\mathrm{a}}$ \\
2-Methylpropyl acetate & $1.81 \pm 0.62^{\mathrm{a}}$ & $3.40 \pm 0.28^{\mathrm{a}}$ & $2.08 \pm 0.12^{\mathrm{a}}$ & $2.28 \pm 0.04^{\mathrm{a}}$ \\
2-Methylpropyl butanoate & $2.07 \pm 0.59^{\mathrm{a}}$ & $2.17 \pm 0.16^{\mathrm{a}}$ & $1.43 \pm 0.29^{\mathrm{a}}$ & $2.24 \pm 0.17^{\mathrm{a}}$ \\
3-Methylbutyl acetate & $12.21 \pm 2.20^{\mathrm{a}}$ & $14.21 \pm 0.89^{\mathrm{a}}$ & $12.81 \pm 1.03^{\mathrm{a}}$ & $10.98 \pm 0.38^{\mathrm{a}}$ \\
3-Methylbutyl butanoate & $2.04 \pm 0.27^{\mathrm{a}}$ & $1.55 \pm 0.20^{\mathrm{a}}$ & $1.72 \pm 0.86^{\mathrm{a}}$ & $1.85 \pm 0.49^{\mathrm{a}}$ \\
3-Methylbutyl lactate & $\mathrm{ND}$ & $5.00 \pm 0.65^{\mathrm{a}}$ & $1.28 \pm 0.49^{\mathrm{b}}$ & $4.08 \pm 0.92^{\mathrm{a}}$ \\
Total & $47.76 \pm 0.45$ & $115.76 \pm 0.31$ & $128.18 \pm 0.63$ & $63.68 \pm 0.39$ \\
\hline
\end{tabular}

${ }^{\mathrm{a}-\mathrm{c}}$ Means $\pm \mathrm{SD}$ within a row with no common superscript differ $(P<0.01)$.

${ }^{1}$ Results are expressed as square roots $\left(\right.$ area $/ 10^{5}$ ) from a triplicate analysis of each cheese. $\mathrm{P}$ and $\mathrm{T}$ refer to the cheeses ripened in plastic or tulum materials, respectively; 1 and 2 refer to the cheeses manufactured in dairies 1 and 2 , respectively. $\mathrm{ND}=$ not detected. 
Table 5. Concentrations of methyl ketones in 90-d-old Tulum cheeses ripened in plastic $(\mathrm{P})$ or goat's skin bags $(\mathrm{T})^{1}$

\begin{tabular}{lrrrr}
\hline & \multicolumn{5}{c}{ Cheese } \\
\cline { 2 - 5 } Methyl ketone & \multicolumn{1}{c}{$\mathrm{P} 1$} & \multicolumn{1}{c}{$\mathrm{P} 2$} & $\mathrm{~T} 1$ & $\mathrm{~T} 2$ \\
\hline 2-Propanone & $17.03 \pm 0.27^{\mathrm{a}}$ & $8.40 \pm 0.56^{\mathrm{c}}$ & $4.87 \pm 0.27^{\mathrm{d}}$ & $12.53 \pm 0.21^{\mathrm{b}}$ \\
2-Butanone & $45.05 \pm 1.10^{\mathrm{a}}$ & $37.67 \pm 0.51^{\mathrm{b}}$ & $35.74 \pm 1.13^{\mathrm{b}}$ & $38.69 \pm 1.09^{\mathrm{b}}$ \\
2-Pentanone & $15.01 \pm 0.66^{\mathrm{b}}$ & $7.36 \pm 0.23^{\mathrm{c}}$ & $\mathrm{ND}$ & $21.55 \pm 0.33^{\mathrm{a}}$ \\
2-Hexanone & $1.45 \pm 0.09^{\mathrm{b}}$ & $\mathrm{ND}$ & $\mathrm{ND}$ & $2.25 \pm 0.07^{\mathrm{a}}$ \\
2-Heptanone & $11.96 \pm 2.03^{\mathrm{a}}$ & $6.32 \pm 1.45^{\mathrm{a}}$ & $4.66 \pm 0.61^{\mathrm{a}}$ & $14.91 \pm 1.28^{\mathrm{a}}$ \\
2-Octanone & $0.91 \pm 0.23^{\mathrm{a}}$ & $1.12 \pm 0.06^{\mathrm{a}}$ & $0.68 \pm 0.31^{\mathrm{a}}$ & $0.89 \pm 0.34^{\mathrm{a}}$ \\
2-Nonanone & $2.73 \pm 0.39^{\mathrm{a}}$ & $2.47 \pm 0.15^{\mathrm{a}}$ & $1.62 \pm 0.66^{\mathrm{a}}$ & $4.14 \pm 0.63^{\mathrm{a}}$ \\
3-Hydroxy 2-butanone & $14.43 \pm 1.13^{\mathrm{a}}$ & $6.80 \pm 1.97^{\mathrm{a}}$ & $11.32 \pm 0.43^{\mathrm{a}}$ & $14.65 \pm 0.80^{\mathrm{a}}$ \\
3-Hydroxy 2-pentanone & $1.49 \pm 0.08^{\mathrm{a}}$ & $0.77 \pm 0.14^{\mathrm{b}}$ & $0.74 \pm 0.05^{\mathrm{b}}$ & $1.67 \pm 0.07^{\mathrm{a}}$ \\
2-Hydroxy 3-pentanone & $1.07 \pm 0.04^{\mathrm{a}}$ & $0.63 \pm 0.12^{\mathrm{b}}$ & $0.66 \pm 0.05^{\mathrm{b}}$ & $1.17 \pm 0.03^{\mathrm{a}}$ \\
Diacetyl & $14.90 \pm 0.91^{\mathrm{b}}$ & $7.40 \pm 0.91^{\mathrm{c}}$ & $25.33 \pm 0.84^{\mathrm{a}}$ & $14.78 \pm 1.07^{\mathrm{b}}$ \\
2,3-Pentanedione & $1.88 \pm 0.24^{\mathrm{a}}$ & $0.58 \pm 0.50^{\mathrm{a}}$ & $1.86 \pm 0.16^{\mathrm{a}}$ & $1.77 \pm 0.18^{\mathrm{a}}$ \\
Total & $127.91 \pm 0.60$ & $79.52 \pm 0.55$ & $87.47 \pm 0.38$ & $128.99 \pm 0.51$ \\
\hline
\end{tabular}

${ }^{\mathrm{a}-\mathrm{c}}$ Means $\pm \mathrm{SD}$ within a row with no common superscript differ $(P<0.01)$.

${ }^{1}$ Results are expressed as square roots $\left(\right.$ area $/ 10^{5}$ ) from a triplicate analysis of each cheese. $\mathrm{P}$ and $\mathrm{T}$ refer to the cheeses ripened in plastic or tulum materials, respectively; 1 and 2 refer to the cheeses manufactured in dairies 1 and 2 , respectively. ND = not detected.

cheese (Unsal, 2003). Therefore, one can conclude that the concentration of methyl ketones, which are reduced to their corresponding secondary alcohols, characterizes the aroma profile of Tulum cheese.

Aldehydes. Aldehydes are produced by the catabolism of fatty acids or AA via decarboxylation or deamination. Aldehydes are transitory compounds and do not accumulate in cheese because they are transformed rapidly to alcohols or to the corresponding acids (Dunn and Lindsay, 1985). Seven aldehydes were identified in Tulum cheeses (Table 6). Acetaldehyde, 2-propanal, 2methyl propanal, and 3-methyl butanal were at the highest concentrations in P1 cheese, and significant differences in the concentrations of 3-methyl butanal $(P<0.05)$ and 2 -furancarboxaldehyde $(P<0.001)$ were found in the cheeses. 2-Furancarboxaldehyde was not determined in the $\mathrm{P} 1$ and $\mathrm{T} 2$ cheeses, and its concentrations in the $\mathrm{P} 2$ and $\mathrm{T} 1$ cheeses were 0.38 and 0.39 units, respectively. Benzaldehyde, which is an important aldehyde in cheese, was present in all cheeses, but there were no significant differences between the cheeses. High concentrations of acetaldehyde and 3-methyl butanal were found in all cheeses. Acetaldehyde is produced by degradation of Thr or fermentation of glucose by the action of lactic acid bacteria (Molimard and Spinnler, 1996). Degradation of AA by Strecker degradation is important for the formation of aldehydes; thus, 2-methyl propanal, 2-methyl butanal, and 3-methyl butanal were produced from Val, Ile, and Leu, respectively (Urbach, 1995). Aldehydes may contribute to the flavor of Tulum cheese because of their low perception thresholds.

Table 6. Concentrations of aldehydes in 90 -d-old Tulum cheeses ripened in plastic $(\mathrm{P})$ or goat's skin bags $(\mathrm{T})^{1}$

\begin{tabular}{lcccc}
\hline & \multicolumn{4}{c}{ Cheese } \\
\cline { 2 - 5 } Aldehyde & P1 & P2 & T1 & T2 \\
\hline Acetaldehyde & $4.30 \pm 0.73^{\mathrm{a}}$ & $2.59 \pm 0.28^{\mathrm{a}}$ & $2.97 \pm 0.17^{\mathrm{a}}$ & $3.64 \pm 0.59^{\mathrm{a}}$ \\
2-Propanal & $4.04 \pm 0.18^{\mathrm{a}}$ & $2.53 \pm 0.23^{\mathrm{a}}$ & $2.73 \pm 0.19^{\mathrm{a}}$ & $3.69 \pm 0.12^{\mathrm{a}}$ \\
2-Methyl propanal & $2.44 \pm 0.30^{\mathrm{a}}$ & $0.93 \pm 0.07^{\mathrm{a}}$ & $0.97 \pm 0.21^{\mathrm{a}}$ & $2.27 \pm 0.36^{\mathrm{a}}$ \\
2-Methyl butanal & $1.37 \pm 0.10^{\mathrm{a}}$ & $0.89 \pm 0.10^{\mathrm{a}}$ & $0.65 \pm 0.05^{\mathrm{a}}$ & $1.25 \pm 0.17^{\mathrm{a}}$ \\
3-Methyl butanal & $6.74 \pm 0.69^{\mathrm{a}}$ & $2.17 \pm 0.20^{\mathrm{a}}$ & $2.09 \pm 0.14^{\mathrm{b}}$ & $6.58 \pm 0.66^{\mathrm{a}}$ \\
2-Furancarboxaldehyde & $\mathrm{ND}$ & $0.38 \pm 0.01^{\mathrm{a}}$ & $0.39 \pm 0.01^{\mathrm{a}}$ & $\mathrm{ND}$ \\
Benzaldehyde & $1.11 \pm 0.26^{\mathrm{a}}$ & $1.45 \pm 0.07^{\mathrm{a}}$ & $1.22 \pm 0.44^{\mathrm{a}}$ & $1.23 \pm 0.11^{\mathrm{a}}$ \\
Total & $20.00 \pm 0.32$ & $10.94 \pm 0.14$ & $11.02 \pm 0.17$ & $18.66 \pm 0.29$ \\
\hline
\end{tabular}

${ }^{\mathrm{a}, \mathrm{b}}$ Means $\pm \mathrm{SD}$ within a row with no common superscript differ $(P<0.01)$.

${ }^{1}$ Results are expressed as square roots $\left(\right.$ area $/ 10^{5}$ ) from a triplicate analysis of each cheese. $\mathrm{P}$ and $\mathrm{T}$ refer to the cheeses ripened in plastic or tulum materials, respectively; 1 and 2 refer to the cheeses manufactured in dairies 1 and 2 , respectively. ND = not detected. 
Table 7. Concentrations of alcohols in 90 -d-old Tulum cheeses ripened in plastic $(\mathrm{P})$ or goat's skin bags $(\mathrm{T})^{1}$

\begin{tabular}{|c|c|c|c|c|}
\hline \multirow[b]{2}{*}{ Alcohol } & \multicolumn{4}{|c|}{ Cheese } \\
\hline & $\mathrm{P} 1$ & $\mathrm{P} 2$ & $\mathrm{~T} 1$ & $\mathrm{~T} 2$ \\
\hline Ethanol & $5.85 \pm 0.92^{\mathrm{c}}$ & $29.61 \pm 1.23^{b}$ & $39.06 \pm 1.45^{\mathrm{a}}$ & $7.45 \pm 1.04^{\mathrm{c}}$ \\
\hline 1-Propanol & $4.25 \pm 1.18^{\mathrm{b}}$ & $12.52 \pm 0.51^{\mathrm{a}}$ & $16.82 \pm 0.94^{\mathrm{a}}$ & $3.86 \pm 0.67^{\mathrm{b}}$ \\
\hline 2-Methyl 1-propanol & $16.20 \pm 1.19^{\mathrm{a}}$ & $16.36 \pm 0.17^{\mathrm{a}}$ & $6.67 \pm 0.19^{b}$ & $13.41 \pm 1.20^{\mathrm{ab}}$ \\
\hline 1-Butanol & $1.10 \pm 0.23^{\mathrm{c}}$ & $4.49 \pm 0.18^{\mathrm{b}}$ & $8.74 \pm 0.24^{\mathrm{a}}$ & $1.15 \pm 0.17^{\mathrm{c}}$ \\
\hline 2-Methyl 1-butanol & $19.20 \pm 0.21^{\mathrm{a}}$ & $19.37 \pm 0.15^{\mathrm{a}}$ & $9.29 \pm 0.50^{\mathrm{c}}$ & $15.54 \pm 0.07^{\mathrm{b}}$ \\
\hline 3-Methyl 1-butanol & $37.88 \pm 0.40^{\mathrm{a}}$ & $35.56 \pm 0.67^{\mathrm{a}}$ & $19.88 \pm 1.20^{\mathrm{c}}$ & $30.33 \pm 0.58^{\mathrm{b}}$ \\
\hline 3-Methyl 3-buten-1-ol & $2.51 \pm 0.18^{\mathrm{a}}$ & $5.18 \pm 0.24^{\mathrm{a}}$ & $4.63 \pm 0.36^{\mathrm{a}}$ & $2.56 \pm 0.39^{\mathrm{a}}$ \\
\hline 3-Methyl 2-buten-1-ol & $1.23 \pm 0.03^{\mathrm{a}}$ & $1.72 \pm 0.03^{\mathrm{a}}$ & $1.74 \pm 0.25^{\mathrm{a}}$ & $1.36 \pm 0.13^{\mathrm{a}}$ \\
\hline 1-Pentanol & $3.52 \pm 0.18^{\mathrm{b}}$ & $6.01 \pm 0.26^{\mathrm{a}}$ & $5.64 \pm 0.43^{\mathrm{a}}$ & $3.41 \pm 0.23^{\mathrm{b}}$ \\
\hline 1-Hexanol & $2.37 \pm 0.19^{b}$ & $4.72 \pm 0.05^{\mathrm{a}}$ & $5.26 \pm 0.39^{\mathrm{a}}$ & $2.96 \pm 0.41^{\mathrm{b}}$ \\
\hline 2-Ethyl 1-hexanol & $1.17 \pm 0.08^{\mathrm{a}}$ & $1.16 \pm 0.02^{\mathrm{a}}$ & $0.88 \pm 0.20^{\mathrm{a}}$ & $1.09 \pm 0.12^{\mathrm{a}}$ \\
\hline 1-Heptanol & $1.26 \pm 0.09^{\mathrm{a}}$ & $2.08 \pm 0.10^{\mathrm{a}}$ & $1.84 \pm 0.28^{\mathrm{a}}$ & $1.55 \pm 0.08^{\mathrm{a}}$ \\
\hline 1-Octanol & $0.92 \pm 0.04^{\mathrm{a}}$ & $1.24 \pm 0.04^{\mathrm{a}}$ & $1.08 \pm 0.23^{\mathrm{a}}$ & $1.11 \pm 0.05^{\mathrm{a}}$ \\
\hline 2-Propanol & $7.90 \pm 0.42^{\mathrm{a}}$ & $7.70 \pm 0.39^{a}$ & $4.21 \pm 0.36^{\mathrm{b}}$ & $5.06 \pm 0.04^{\mathrm{b}}$ \\
\hline 2-Butanol & $32.98 \pm 1.35^{\mathrm{a}}$ & $39.11 \pm 1.91^{\mathrm{a}}$ & $33.29 \pm 1.48^{\mathrm{a}}$ & $22.39 \pm 0.17^{\mathrm{b}}$ \\
\hline 2-Pentanol & $8.30 \pm 0.73^{\mathrm{a}}$ & $5.68 \pm 0.54^{\mathrm{b}}$ & $3.53 \pm 0.37^{\mathrm{b}}$ & $8.63 \pm 0.06^{\mathrm{a}}$ \\
\hline 2-Hexanol & $1.35 \pm 0.39^{\mathrm{a}}$ & $1.30 \pm 0.10^{\mathrm{a}}$ & $0.61 \pm 0.05^{\mathrm{a}}$ & $1.58 \pm 0.01^{\mathrm{a}}$ \\
\hline 2-Heptanol & $4.02 \pm 0.62^{\mathrm{a}}$ & $3.93 \pm 0.35^{\mathrm{a}}$ & $3.08 \pm 0.39^{\mathrm{a}}$ & $5.47 \pm 0.43^{\mathrm{a}}$ \\
\hline 2-Octanol & ND & ND & $0.50 \pm 0.13^{\mathrm{a}}$ & $0.64 \pm 0.02^{\mathrm{a}}$ \\
\hline 2-Nonanol & $0.80 \pm 0.17^{\mathrm{a}}$ & $1.24 \pm 0.21^{\mathrm{a}}$ & $1.02 \pm 0.21^{\mathrm{a}}$ & $1.04 \pm 0.07^{\mathrm{a}}$ \\
\hline 1-Methoxy 2-propanol & $8.84 \pm 1.57^{\mathrm{a}}$ & $5.81 \pm 0.80^{\mathrm{a}}$ & $4.21 \pm 0.63^{\mathrm{a}}$ & $10.03 \pm 0.42^{\mathrm{a}}$ \\
\hline Phenethyl alcohol & $11.17 \pm 1.82^{\mathrm{a}}$ & $11.99 \pm 0.16^{\mathrm{a}}$ & $5.02 \pm 3.48^{\mathrm{a}}$ & $7.65 \pm 1.06^{\mathrm{a}}$ \\
\hline Total & $172.81 \pm 0.55$ & $216.78 \pm 0.37$ & $176.97 \pm 0.63$ & $148.27 \pm 0.34$ \\
\hline
\end{tabular}

${ }^{\mathrm{a}-\mathrm{c}}$ Means $\pm \mathrm{SD}$ within a row with no common superscript differ $(P<0.01)$.

${ }^{1}$ Results are expressed as square roots $\left(\right.$ area $/ 10^{5}$ ) from a triplicate analysis of each cheese. $\mathrm{P}$ and $\mathrm{T}$ refer to the cheeses ripened in plastic or tulum materials, respectively; 1 and 2 refer to the cheeses manufactured in dairies 1 and 2 , respectively. $\mathrm{ND}=$ not detected.

Alcohols. Alcohols are important volatile compounds that may contribute to the flavor of Tulum cheese. The use of raw milk in the manufacture of Tulum cheese may have an effect on the higher concentrations of alcohols. Ortigosa et al. (2005) reported that the pasteurization of cheese milk has a negative effect on the formation of alcohols in cheese. On the contrary, Shakeel-UrRehman et al. (2000a) suggested that the pasteurization process does not significantly influence the formation of all alcohols. Alcohols are synthesized via many metabolic pathways (i.e, metabolism of lactose and AA, degradation of methyl ketones and linoleic and linolenic acids; Molimard and Spinnler, 1996). Twenty-two alcohols were identified in the Tulum cheese, as shown in Table 7. Among the alcohols, ethanol, 2-methyl 1propanol, 2-methyl 1-butanol, 3-methyl 1-butanol, 2butanol, 2-pentanol, 1-methoxy 2-propanol, and phenethyl alcohol were detected in large quantities in the Tulum cheeses. Four methyl alcohols were identified in the cheeses, and these are generated by the metabo-

Table 8. Concentrations of sulfur compounds in 90 -d-old Tulum cheeses ripened in plastic $(\mathrm{P})$ or goat's skin bags $(\mathrm{T})^{1}$

\begin{tabular}{lcccc}
\hline & \multicolumn{4}{c}{ Cheese } \\
\cline { 2 - 5 } Sulfur compound & $\mathrm{P} 1$ & $\mathrm{P} 2$ & $\mathrm{~T} 1$ & $\mathrm{~T} 2$ \\
\hline Methanethiol & $\mathrm{ND}$ & $\mathrm{ND}$ & $0.29 \pm 0.02^{\mathrm{a}}$ & $\mathrm{ND}$ \\
Carbon disulfide & $0.84 \pm 0.03^{\mathrm{b}}$ & $1.26 \pm 0.03^{\mathrm{a}}$ & $0.56 \pm 0.04^{\mathrm{b}}$ & $0.70 \pm 0.03^{\mathrm{b}}$ \\
Dimethyl sulfide & $1.00 \pm 0.03^{\mathrm{a}}$ & $1.24 \pm 0.04^{\mathrm{a}}$ & $0.63 \pm 0.05^{\mathrm{b}}$ & $0.66 \pm 0.01^{\mathrm{b}}$ \\
Dimethyl disulfide & $1.24 \pm 0.06^{\mathrm{a}}$ & $1.42 \pm 0.01^{\mathrm{a}}$ & $0.81 \pm 0.08^{\mathrm{b}}$ & $1.25 \pm 0.03^{\mathrm{a}}$ \\
Dimethyl trisulfide & $0.39 \pm 0.11^{\mathrm{a}}$ & $0.49 \pm 0.04^{\mathrm{a}}$ & $0.16 \pm 0.14^{\mathrm{a}}$ & $0.59 \pm 0.05^{\mathrm{a}}$ \\
3-Methylthio 1-propanol & $0.98 \pm 0.04^{\mathrm{a}}$ & $1.12 \pm 0.04^{\mathrm{a}}$ & $0.84 \pm 0.10^{\mathrm{a}}$ & $0.88 \pm 0.05^{\mathrm{a}}$ \\
Dimethyl sulfone & $1.75 \pm 0.24^{\mathrm{a}}$ & $1.35 \pm 0.14^{\mathrm{a}}$ & $1.26 \pm 0.17^{\mathrm{a}}$ & $1.42 \pm 0.31^{\mathrm{a}}$ \\
Total & $6.20 \pm 0.07$ & $6.88 \pm 0.04$ & $4.54 \pm 0.09$ & $5.49 \pm 0.07$ \\
\hline
\end{tabular}

\footnotetext{
${ }^{\mathrm{a}, \mathrm{b}}$ Means $\pm \mathrm{SD}$ within a row with no common superscript differ $(P<0.01)$.

${ }^{1}$ Results are expressed as square roots $\left(\right.$ area $/ 10^{5}$ ) from a triplicate analysis of each cheese. $\mathrm{P}$ and $\mathrm{T}$ refer to the cheeses ripened in plastic or tulum materials, respectively; 1 and 2 refer to the cheeses manufactured in dairies 1 and 2 , respectively. $\mathrm{ND}=$ not detected.
} 
Table 9. Concentrations of terpenes in 90-d-old Tulum cheeses ripened in plastic $(\mathrm{P})$ or goat's skin bags $(\mathrm{T})^{1}$

\begin{tabular}{lcrrr}
\hline & \multicolumn{4}{c}{ Cheese } \\
\cline { 2 - 5 } Terpene & P1 & P2 & T1 & T2 \\
\hline$\alpha$-Pinene & $5.32 \pm 0.10^{\mathrm{a}}$ & $5.11 \pm 0.11^{\mathrm{a}}$ & $4.90 \pm 0.16^{\mathrm{a}}$ & $4.94 \pm 0.07^{\mathrm{a}}$ \\
Carane & $5.34 \pm 0.75^{\mathrm{a}}$ & $5.93 \pm 0.46^{\mathrm{a}}$ & $5.76 \pm 0.61^{\mathrm{a}}$ & $6.09 \pm 0.17^{\mathrm{a}}$ \\
$\beta$-Pinene & $2.74 \pm 0.08^{\mathrm{a}}$ & $2.39 \pm 0.87^{\mathrm{a}}$ & $2.86 \pm 0.15^{\mathrm{a}}$ & $2.89 \pm 0.14^{\mathrm{a}}$ \\
Limonene & $1.83 \pm 0.21^{\mathrm{a}}$ & $2.03 \pm 0.15^{\mathrm{a}}$ & $1.85 \pm 0.27^{\mathrm{a}}$ & $1.81 \pm 0.17^{\mathrm{a}}$ \\
$p$-Cymene & $5.65 \pm 0.94^{\mathrm{a}}$ & $7.69 \pm 0.39^{\mathrm{a}}$ & $6.55 \pm 1.66^{\mathrm{a}}$ & $7.48 \pm 0.45^{\mathrm{a}}$ \\
$\beta$-Patchoulene & $0.56 \pm 0.02^{\mathrm{a}}$ & $0.57 \pm 0.02^{\mathrm{a}}$ & $0.52 \pm 0.06^{\mathrm{a}}$ & $0.50 \pm 0.02^{\mathrm{a}}$ \\
Total & $21.43 \pm 0.35$ & $23.70 \pm 0.33$ & $22.44 \pm 0.48$ & $23.70 \pm 0.17$ \\
\hline
\end{tabular}

${ }^{\mathrm{a}}$ Means $\pm \mathrm{SD}$ within a row with no common superscript differ $(P<0.01)$.

${ }^{1}$ Results are expressed as square roots $\left(\right.$ area $/ 10^{5}$ ) from a triplicate analysis of each cheese. $\mathrm{P}$ and $\mathrm{T}$ refer to the cheeses ripened in plastic or tulum materials, respectively; 1 and 2 refer to the cheeses manufactured in dairies 1 and 2, respectively.

lism of branched-chain AA (Molimard and Spinnler, 1996). The presence of the branched-chain primary alcohols 2-methyl 1-butanol, 2-methyl 1-propanol, and 3methyl 1-butanol indicates conversion of the aldehydes produced from Ile, Val, and Leu, respectively (Engels et al., 1997). Very small quantities of 1-octanol, 2-hexanol, 2-octanol, and 2-nonanol were detected in the cheeses, but 2-octanol was not detected in the P1 and P2 cheeses. Ethanol is mainly produced by the fermentation of lactose and by the catabolism of Ala, and it plays an important role in the formation of esters. Ethanol is also found as a principal alcohol in other types of cheeses, such as Feta (Horwood et al., 1981; Bintis and Robinson, 2004), Roncal (Ortigosa et al., 2001), Minas (Correa Lelles Nogueira et al., 2005), Cheddar (Arora et al., 1995), and Hispanico (Oumer et al., 2001).

Sulfur Compounds. Sulfur compounds, such as hydrogen sulfide and methanethiol, are mainly produced by degradation of Met or Met-containing peptides during cheese ripening, and methanethiol can be converted to dimethyl disulfide and dimethyl trisulfide by oxidative reactions (Engels et al., 1997). The concentrations of sulfur compounds are shown in Table 8, and the most abundant sulfur compounds in the cheeses were dimethyl disulfide and dimethyl sulfone. The concentrations of sulfur compounds in $\mathrm{P}$ cheeses were higher

Table 10. Concentrations of miscellaneous compounds in 90-d-old Tulum cheeses ripened in plastic $(\mathrm{P})$ or goat's skin bags $(\mathrm{T})^{1}$

\begin{tabular}{lrrrr}
\hline & \multicolumn{4}{c}{ Cheese } \\
\cline { 2 - 5 } Miscellaneous compounds & \multicolumn{1}{c}{$\mathrm{P} 1$} & \multicolumn{1}{c}{$\mathrm{P} 2$} & \multicolumn{1}{c}{$\mathrm{T} 1$} & \multicolumn{1}{c}{$\mathrm{T} 2$} \\
\hline Phenol & $0.94 \pm 0.09^{\mathrm{a}}$ & $0.99 \pm 0.03^{\mathrm{a}}$ & $0.80 \pm 0.13^{\mathrm{a}}$ & $0.91 \pm 0.04^{\mathrm{a}}$ \\
2-Methyl phenol & $1.06 \pm 0.14^{\mathrm{a}}$ & $1.34 \pm 0.05^{\mathrm{a}}$ & $1.07 \pm 0.27^{\mathrm{a}}$ & $1.22 \pm 0.08^{\mathrm{a}}$ \\
4-Methyl phenol & $0.45 \pm 0.06^{\mathrm{a}}$ & $0.57 \pm 0.03^{\mathrm{a}}$ & $0.46 \pm 0.12^{\mathrm{a}}$ & $0.51 \pm 0.04^{\mathrm{a}}$ \\
p-Methyl anisole & $0.92 \pm 0.12^{\mathrm{a}}$ & $0.84 \pm 0.07^{\mathrm{a}}$ & $0.59 \pm 0.28^{\mathrm{a}}$ & $1.06 \pm 0.20^{\mathrm{a}}$ \\
Benzene & $6.37 \pm 0.17^{\mathrm{a}}$ & $7.14 \pm 0.64^{\mathrm{a}}$ & $7.18 \pm 0.41^{\mathrm{a}}$ & $7.00 \pm 0.15^{\mathrm{a}}$ \\
Toluene & $20.20 \pm 1.07^{\mathrm{a}}$ & $14.29 \pm 1.48^{\mathrm{a}}$ & $18.77 \pm 1.72^{\mathrm{a}}$ & $25.32 \pm 0.42^{\mathrm{a}}$ \\
Ethyl benzene & $1.67 \pm 0.14^{\mathrm{a}}$ & $1.52 \pm 0.07^{\mathrm{a}}$ & $1.57 \pm 0.26^{\mathrm{a}}$ & $2.22 \pm 0.20^{\mathrm{a}}$ \\
Styrene & $2.19 \pm 0.42^{\mathrm{a}}$ & $2.34 \pm 0.12^{\mathrm{a}}$ & $1.95 \pm 0.49^{\mathrm{a}}$ & $2.89 \pm 0.28^{\mathrm{a}}$ \\
Pentane & $2.32 \pm 0.20^{\mathrm{a}}$ & $3.16 \pm 0.23^{\mathrm{a}}$ & $1.93 \pm 0.08^{\mathrm{a}}$ & $1.90 \pm 0.12^{\mathrm{a}}$ \\
Hexane & $7.27 \pm 0.28^{\mathrm{a}}$ & $4.33 \pm 0.14^{\mathrm{b}}$ & $5.97 \pm 0.14^{\mathrm{b}}$ & $8.69 \pm 0.22^{\mathrm{a}}$ \\
Octane & $2.35 \pm 0.42^{\mathrm{a}}$ & $2.76 \pm 0.14^{\mathrm{a}}$ & $3.48 \pm 0.33^{\mathrm{a}}$ & $3.73 \pm 0.10^{\mathrm{a}}$ \\
3-Octene & $2.37 \pm 0.25^{\mathrm{a}}$ & $2.69 \pm 0.01^{\mathrm{a}}$ & $2.78 \pm 0.32^{\mathrm{a}}$ & $3.28 \pm 0.11^{\mathrm{a}}$ \\
2,2,4,6,6-Pentamethyl heptane & $3.93 \pm 0.25^{\mathrm{a}}$ & $2.34 \pm 0.25^{\mathrm{a}}$ & $3.22 \pm 0.37^{\mathrm{a}}$ & $4.86 \pm 0.17^{\mathrm{a}}$ \\
3,7-Dimethyl-2-octene & $3.45 \pm 0.35^{\mathrm{a}}$ & $3.79 \pm 0.18^{\mathrm{a}}$ & $3.95 \pm 0.87^{\mathrm{a}}$ & $4.84 \pm 0.25^{\mathrm{a}}$ \\
3,7-Dimethyl-1,6-octadiene & $4.38 \pm 0.42^{\mathrm{a}}$ & $4.77 \pm 0.23^{\mathrm{a}}$ & $4.03 \pm 0.71^{\mathrm{a}}$ & $4.73 \pm 0.50^{\mathrm{a}}$ \\
Diethyl ether & $1.26 \pm 0.06^{\mathrm{a}}$ & $0.87 \pm 0.01^{\mathrm{b}}$ & $0.59 \pm 0.04^{\mathrm{c}}$ & $0.94 \pm 0.03^{\mathrm{b}}$ \\
Chloroform & $3.20 \pm 0.08^{\mathrm{ab}}$ & $2.14 \pm 0.11^{\mathrm{b}}$ & $1.91 \pm 0.08^{\mathrm{b}}$ & $3.64 \pm 0.08^{\mathrm{a}}$ \\
Bromoform & $0.50 \pm 0.09^{\mathrm{a}}$ & $0.17 \pm 0.15^{\mathrm{a}}$ & $0.24 \pm 0.11^{\mathrm{a}}$ & $0.52 \pm 0.02^{\mathrm{a}}$ \\
Carbon dioxide & $11.18 \pm 0.72^{\mathrm{a}}$ & $9.15 \pm 0.96^{\mathrm{a}}$ & $6.60 \pm 0.46^{\mathrm{a}}$ & $7.92 \pm 0.54^{\mathrm{a}}$ \\
Total & $76.01 \pm 0.28$ & $65.22 \pm 0.26$ & $67.09 \pm 0.38$ & $86.16 \pm 0.19$ \\
\hline
\end{tabular}

${ }^{\mathrm{a}-\mathrm{c}}$ Means $\pm \mathrm{SD}$ within a row with no common superscript differ $(P<0.01)$.

${ }^{1}$ Results are expressed as square roots $\left(\right.$ area/ $/ 10^{5}$ ) from a triplicate analysis of each cheese. $\mathrm{P}$ and $\mathrm{T}$ refer to the cheeses ripened in plastic or tulum materials, respectively; 1 and 2 refer to the cheeses manufactured in dairies 1 and 2, respectively. 
than those of T cheeses. Significant differences were noted among the cheeses for levels of some of these compounds, including methanethiol, carbon disulfide, dimethyl sulfide, and dimethyl disulfide. Methanethiol was not detected in the experimental cheeses except in the $\mathrm{T} 1$ cheese; this compound may be converted to dimethyl disulfide and dimethyl trisulfide by oxidative reactions. Indeed, the concentrations of dimethyl disulfide and dimethyl trisulfide were higher in the P1, P2, and T2 cheeses than in the T1 cheese. However, Urbach (1997) reported that methanethiol is a key, essential compound in Cheddar cheese aroma, and a strong correlation between the concentration of methanethiol and the intensity of Cheddar flavor was found by Dimos et al. (1996).

Terpenes. Terpenes in milk originate from plants in the feed mixture or pasture (Curioni and Bosset, 2002). Seven terpenes were identified in Tulum cheeses; however, no significant differences were found among the cheeses in terms of their concentrations (Table 9). We concluded that ripening container (tulum or plastic) had no role in the formation of terpenes in cheeses; that is, all cheese samples had similar levels of terpenes because the cheese milk was obtained from the same area. The concentrations of $\alpha$-pinene, carane, and $p$ cymene were higher than concentrations of the other compounds. $\alpha$-Pinene was also identified in Cheddar (Curioni and Bosset, 2002), Minas (Correa Lelles Nogueira et al., 2005), and Manchego (Fernandez-Garcia et al., 2002) cheeses. Limonene was found in lower levels in the cheeses compared with other terpenes.

Miscellaneous Compounds. A number of miscellaneous compounds were identified in Tulum cheeses and are listed in Table 10. Eight aromatic compounds, including some phenolic compounds (phenol, 2-methyl phenol, and 4-methyl phenol), hydrocarbons (such as pentane, hexane, octane, 3-octene, 2,2,4,6,6-pentamethyl heptane, 3,7-dimethyl-2-octene, and 3,7-dimethyl-1,6-octadiene), $p$-methyl anisole, benzene, toluene, and styrene were found in the cheeses. Phenolic compounds, which are mainly present in sheep's milk as conjugates with phosphate or sulfate, contribute to cheese aroma at about the threshold concentration (Urbach, 1997). The concentrations of phenolic compounds did not differ among the cheeses. Hydrocarbons are secondary products of lipid autoxidation and are precursors for the formation of aromatic compounds (Arora et al., 1995). No significant differences were noted among the cheeses in terms of the concentrations of phenolic compounds and hydrocarbons, with the exception of hexane, which had the highest concentration in the T2 cheese. A high concentration of toluene was found in the experimental cheeses. Toluene in cheese originates from the degradation of carotene in milk or could be related to the use of solvent during aroma analysis (Molimard and Spinnler, 1996). Toluene has already been identified at high levels in Feta-type (Bintis and Robinson, 2004) and Spanish ewe's milk semihard (Mariaca et al., 2001) cheeses. Styrene, which has a strong plastic odor, was also found in Tulum cheese, and differences between cheeses ripened under different conditions were not significant. Diethyl ether, chloroform, and bromoform were also detected in Tulum cheeses, and high concentrations of diethyl ether and chloroform were determined in the $\mathrm{P} 1$ and $\mathrm{T} 2$ cheeses. In addition, high concentrations of carbon dioxide, also a metabolic product, were present in the cheeses. Lactones were not detected in the cheeses; however, many $\delta$ - and $\gamma$ lactones were previously identified in Cheddar cheese, and their concentrations correlated well with the development of Cheddar flavor (Shakeel-Ur-Rehman et al., $2000 a, b)$.

\section{CONCLUSIONS}

The results obtained showed that the ripening of Tulum cheese in tulums or plastic material influenced the composition and microbiology of the cheeses during ripening. The moisture contents of the cheeses ripened in tulums decreased continuously, and differences were seen among all cheeses at $150 \mathrm{~d}$ of ripening. Some differences were noted between the cheeses manufactured in the 2 different dairies and ripened in tulums or plastic. Higher microbial counts were detected in the $P$ cheeses than in the $\mathrm{T}$ cheeses. The coliform bacterial counts were higher in the cheeses produced in dairy 2 . The nitrogen fractions increased during ripening, and their concentrations in the cheeses did not differ significantly. The concentrations of most individual FAA were much higher in the T cheeses. Primary proteolysis, detectable by urea-PAGE, was identical in all cheeses during ripening. The peptide profiles of the $\mathrm{pH}$ 4.6soluble and EtOH-s or EtOH-i fractions by RP-HPLC showed differences between the cheeses, and ripening time had a strong effect on the peptide concentrations in these extracts. One hundred volatile components were identified by GC-MS analysis of the cheeses. All samples contained the same aroma compounds, even though their concentrations differed. In general, some minor differences in the cheeses were observed in terms of the ripening container used (tulums or plastic) or the 2 different dairies. This study confirms that ripening container does not play a significant role in the breakdown of proteins. For instance, the principal proteolytic agent responsible for primary proteolysis is the coagulant. The composition of the $T$ cheeses was clearly differentiated from the $\mathrm{P}$ cheeses because of the properties of water and air permeability of the tulum. Some differ- 
ences in the volatile composition of the cheeses could be linked to the specific structure of the tulum.

\section{REFERENCES}

Andrews, A. T. 1983. Proteinases in normal bovine milk and their action on caseins. J. Dairy Res. 50:45-55.

AOAC. 1995. Official Methods of Analysis. Vol. 2. 16th ed. AOAC International, Arlington, VA.

Ardo, Y., and A. Polychroniadou. 1999. Laboratory Manual for Chemical Analysis of Cheese. COST 95, Luxembourg, Luxembourg.

Arora, G., F. Cormier, and B. Lee. 1995. Analysis of odor active volatiles in Cheddar cheese headspace by multidimensional GC/ MS/sniffing. J. Agric. Food Chem. 43:748-752.

Barron, L. J. R., Y. Redondo, M. Aramburu, F. J. Perez-Elotondo, M. Albisu, A. I. Najera, and M. de Renobales. 2005. Variations in volatile compounds and flavour in Idiazabal cheese manufactured from ewe's milk in farmhouse and factory. J. Sci. Food Agric. 85:1660-1671.

Bintis, T., and R. K. Robinson. 2004. A study of the effects of adjunct cultures on the aroma compounds of Feta-type cheese. Food Chem. 88:435-441.

Blakesley, R. W., and J. A. Boezi. 1977. A new staining technique for proteins in polyacrylamide gels using Coomassie Brilliant Blue G250. Anal. Biochem. 82:580-581.

Bosset, J. O., M. Collomb, and R. Sieber. 1993. The aroma composition of Swiss Gruyere cheese IV. The acidic volatile components and their changes in content during ripening. Lebensm. Wiss. Technol. 26:581-592.

Bostan, K., and M. Ugur. 1991. Tulum peynirinde starter kultur kullanim olanaklari. Pages 212-225 in II. Uluslararasi Gida Sempozyumu, Bursa, Turkey.

Bradley, R. L., E. Arnold, D. M. Barbano, R. G. Semerad, D. E. Smith, and B. K. Vines. 1993. Chemical and physical methods. Pages 433-531 in Standard Methods for the Examination of Dairy Products. 16th ed. R. T. Marshall, ed. American Public Health Association, Washington, DC.

Caglar, A. 2001. Cig sutten uretilen ve farkli ambalajlama materyallerinde olgunlastirilan Erzincan Tulum peynirlerinin mikrobiyolojik ozelliklerindeki degismeler. Ataturk Univ. Ziraat Fak. Derg. 32:285-292.

Correa Lelles Nogueira, M., G. Luachevsky, and S. A. Rankin. 2005. A study of volatile composition of Minas cheese. Lebensm. Wiss. Technol. 38:555-563.

Curioni, P. M. G., and J. O. Bosset. 2002. Key odorants in various cheese types as determined by gas chromatography-olfactometry. Int. Dairy J. 12:959-984.

Dimos, A., G. E. Urbach, and A. J. Miller. 1996. Changes in flavour and volatiles of full and reduced fat Cheddar cheese during maturation. Int. Dairy J. 6:981-995.

Dunn, H. C., and R. C. Lindsay. 1985. Evaluation of the role of microbial Strecker-derivated aroma compounds in unclean-type flavor of Cheddar cheese. J. Dairy Sci. 68:2859-2874.

El Soda, M., N. Farkye, J. C. Vuillemard, R. E. Simard, N. F. Olson, W. El Kholy, E. Dako, E. Medrano, M. Gaber, and L. Lim. 1995. Autolysis of lactic acid bacteria: Impact on flavour development in cheese. Pages 2205-2223 in Food Flavours: Generation, Analysis and Process Influence. G. Charalambous, ed. Elsevier Sciences, Amsterdam, the Netherlands.

Engels, W. J. M., R. Dekker, C. De Jong, R. Neeter, and S. Visser. 1997. A comparative study of volatile compounds in the watersoluble fraction of various types of ripened cheese. Int. Dairy J. 7:255-263.

Fernadez-Garcia, E., M. Carbonell, and M. Nunez. 2002. Volatile fraction and sensory characteristics of Manchego cheese. 1. Comparison of raw and pasteurized milk cheese. J. Dairy Res. 69:579-593.

Folkertsma, B., and P. F. Fox. 1992. Use of Cd-ninhydrin reagent to assess proteolysis in cheese during ripening. J. Dairy Res. $59: 217-224$.
Fox, P. F., T. P. O'Connor, P. L. H. McSweeney, T. P. Guinee, and N. M. O'Brien. 1996. Cheese: Physical, chemical, biochemical and nutritional aspects. Adv. Food Nutr. Res. 39:163-328.

Frank, J. F., G. L. Christen, and L. B. Bullerman. 1993. Tests for groups of microorganisms. Pages 271-286 in Standard Methods for the Examination of Dairy Products, R. T. Marshall ed. 16th ed. American Public Health Association, Washington, DC.

Gomez, M. J., S. Garde, P. Gaya, M. Medina, and M. Nunez. 1997. Relationship between level of hydrophobic peptide and bitterness in cheese made from pasteurised and raw milk. J. Dairy Res. 64:289-297.

Guven, M. 1993. Inek, koyun ve keci sutlerinden uretilen ve farkli ambalajlarda olgunlastirilan Tulum peynirlerinin ozellikleri uzerine karsilastirmali bir arastirma. PhD Thesis Cukruva University, Adana, Turkey.

Guven, M., and A. Konar. 1995. Ankara, Istanbul ve Adana piyasalarinda farkli ambalajlarda satilan Tulum peynirlerinin bazi kimyasal ozellikleri ve standarda uygunlugu. Tr. J. Agric. Forest. 19:287-291.

Guven, M., A. Konar, and A. Kleeberger. 1995. Inek, koyun ve keci sutlerinden uretilen ve deri tulumlarda farkli surelerde olgunlastirilan Tulum peynirlerinin bazi mikrobiyolojik ozelliklerinin saptanmasi uzerinde karsilastirmali bir arastirma. Tr. J. Agric. Forest. 19:293-298.

Guven, M., and A. Konar. 1994a. Inek sutlerinden uretilen ve farkli materyallerde olgunlastirilan Tulum peynirlerinin mikrobiyolojik ozellikleri. Gida 19:179-185.

Guven, M., and A. Konar. 1994b. Inek sutlerinden uretilen ve farkli materyallerde olgunlastirilan Tulum peynirlerinin fiziksel, kimyasal ve duyusal ozellikleri. Gida 19:287-293.

Hannon, J. A., M. G. Wilkinson, C. M. Delahunty, J. M. Wallace, P. A. Morrissey, and T. P. Beresford. 2003. Use of autolytic starter systems to accelerate the ripening of Cheddar cheese. Int. Dairy J. 13:313-323.

Hartman, P. A., and W. S. La Grang. 1985. Coliforms bacteria. Pages 173-186 in Standard Methods for the Examination of Dairy Products. 15th ed. G. H. Richardson, ed. American Public Health Association, Washington, DC.

Hayaloglu, A. A., M. Guven, P. F. Fox, and P. L. H. McSweeney. 2005. Influence of starters on chemical, biochemical, and sensory changes in Turkish White-brined cheese during ripening. J. Dairy Sci. 88:3460-3474.

Horwood, J. F., G. T. Lloyd, and W. Stark. 1981. Some flavour compounds of Feta cheese. Aust. J. Dairy Technol. 36:34-37.

International Dairy Federation (IDF). 1982. Determination of the total solid content (cheese and processed cheese). IDF Standard 4A. IDF, Brussels, Belgium.

International Dairy Federation (IDF). 1993. Milk. Determination of the nitrogen (Kjeldahl method) and calculation of the crude protein content. IDF Standard 20B. IDF, Brussels, Belgium.

Kilic, S., and S. Gonc. 1992. Izmir Tulum peynirinin olgunlasmasinda rol oynayan mikroorganizma gruplarinin belirlenmesi uzerine bir arastirma. E.U. Ziraat Fak. Derg. 29:71-78.

Kurt, A., A. Caglar, S. Cakmakci, and N. Akyuz. 1991b. Erzincan Tulum (Savak) peynirinin mikrobiyolojik ozellikleri. Doga Tr. J. Vet. Anim. Sci. 16:41-50.

Kurt, A., S. Cakmakci, A. Caglar, and N. Akyuz. 1991a. Erzincan Tulum (Savak) peynirinin yapilisi, duyusal, fiziksel ve kimyasal ozellikleri uzerinde bir arastirma. Gida 16:295-302.

Lane, C. N., and P. F. Fox. 1997. Role of starter enzymes during ripening of Cheddar cheese made from pasteurized milk under controlled microbiological conditions. Int. Dairy J. 7:55-63.

Lau, K. Y., D. M. Barbano, and R. R. Rasmussen. 1991. Influence of pasteurization of milk on protein breakdown in Cheddar cheese during ageing. J. Dairy Sci. 74:727-740.

Law, J., G. F. Fitzgerald, C. Daly, P. F. Fox, and N. Y. Farkye. 1992. Proteolysis and flavor development in Cheddar cheese made with the single strains Lactococcus lactis ssp. lactis UC317 or Lactococcus lactis ssp. cremoris HP. J. Dairy Sci. 75:1173-1185.

Lee, K. D., C. G. Lo, and J. J. Warthesen. 1996. Removal of bitterness from the bitter peptides extracted from Cheddar cheese with pep- 
tidases from Lactococcus lactis subsp. cremoris SK11. J. Dairy Sci. 79:1521-1528.

Liu, S.-Q., R. Holland, and V. L. Crow. 2004. Esters and their biosynthesis in fermented dairy products: A review. Int. Dairy J. 14:923-945.

Mariaca, R. G., E. Feranadez-Garcia, A. F. Mohedano, and M. Nunez. 2001. Volatile fraction of ewe's milk semi-hard cheese manufactured with and without the addition of cysteine proteinase. Food Sci. Technol. Int. 7:131-139.

McSweeney, P. L. H., and M. J. Sousa. 2000. Biochemical pathways for the production of flavour compounds in cheese during ripening: A review. Lait 80:293-324.

Messer, J. W., H. M. Behney, and L. O. Leudecke. 1985. Microbiological count methods. Pages 133-149 in Standard Methods for the Examination of Dairy Products. 15th ed. G. H. Richardson ed. American Public Health Association, Washington, DC.

Moio, L., and F. Addeo. 1998. Grana Padano cheese aroma. J. Dairy Res. 65:317-333.

Molimard, P., and H. E. Spinnler. 1996. Compounds involved in the flavor of surface mold-ripened cheeses: Origins and properties. J. Dairy Sci. 79:169-184.

Oner, Z., B. Simsek, and O. Sagdic. 2003. Determination of some properties of Turkish Tulum cheeses. Milchwissenschaft 58:152-154.

Ortigosa, M., C. Arizcun, P. Torre, and J. M. Izco. 2005. Use of wild Lactobacillus strains in an adjunct culture for a Roncal-type cheese. J. Dairy Res. 72:168-178.

Ortigosa, M., P. Torre, and J. M. Izco. 2001. Effect of pasteurization of ewe's milk and use of an indigenous starter culture on the volatile compounds and sensory characteristics of Roncal cheese. J. Dairy Sci. 84:1320-1330.

Oumer, A., P. Gaya, E. Fernandez-Garcia, R. Mariaca, S. Garde, M. Medina, and M. Nunez. 2001. Proteolysis and formation of volatile compounds in cheese manufactured with a bacteriocin-producing adjunct culture. J. Dairy Res. 68:117-129.

Patir, B., G. Ates, and A. H. Dincoglu. 2001. Geleneksel yontemle uretilen Tulum peynirinin olgunlastirilmasi sirasinda meydana gelen mikrobiyolojik ve kimyasal degisimler uzerine arastirmalar. F. U. Saglik. Bil. Derg. 15:1-8.

Patir, B., G. Ates, A. H. Dincoglu, and F. Kok. 2000. Elazig'da tuketime sunulan Tulum peynirinin mikrobiyolojik ve kimyasal kal- itesi ile laktik asit bakterileri uzerine arastirmalar. F.U. Saglik Bil. Derg. 14:75-83.

Pawliszyn, J. 1997. Solid Phase Microextraction: Theory and Practice. Wiley-VCH, New York, NY.

SAS Institute. 1995. User's Guide: Statistics. Version 6.12 Ed. SAS Institute, Inc., Cary, NC.

Sengul, M., and S. Cakmakci. 1998. Erzincan Tulum (Savak) peynirinin bazi kalite kriterleri uzerine ambalaj materyali ve olgunlasma suresinin etkisi. Pages 1687-1698 in Dogu Anadolu Tarim Kongresi, Erzurum, Turkey.

Sengul, M., H. Turkoglu, S. Cakmakci, and A. H. Con. 2001. Effect of casing materials and ripening period on some microbiological properties of Tulum cheese. Pakistan J. Biol. Sci. 4:854-857.

Shakeel-Ur-Rehman, J. M. Banks, E. Y. Brechany, D. D. Muir, P. L. H. McSweeney, and P. F. Fox. 2000a. Influence of ripening temperature on the volatiles profile and flavour of Cheddar cheese made from raw and pasteurized milk. Int. Dairy J. 10:55-65.

Shakeel-Ur-Rehman, P. L. H. McSweeney, J. M. Banks, E. Y. Brechany, D. D. Muir, and P. F. Fox. 2000b. Ripening of Cheddar cheese made from blends of raw and pasteurized milk. Int. Dairy J. 10:33-44.

Sousa, M. J., and P. L. H. McSweeney. 2001. Studies on the ripening of Cooleeney, an Irish farmhouse Camembert-type cheese. Irish J. Agric. Food Res. 40:83-95.

Turk Standartlari Enstitusu. 1995. Tulum peyniri, TS 3001. Turk Standartlari Enstitusu, Ankara, Turkey.

Unsal, A. 2003. Sut Uyuyunca-Turkiye Peynirleri. Yapi Kredi Yayinlari, Istanbul, Turkey.

Urbach, G. 1995. Contribution of lactic acid bacteria to flavour compound formation in dairy products. Int. Dairy J. 5:877-903.

Urbach, G. 1997. The chemical and biochemical basis of cheese and milk aroma. Pages 253-298 in Microbiology and Biochemistry of Cheese and Fermented Milk. B. A. Law, ed. Blackie Academic and Professional, London, UK.

Visser, F. M. W. 1977. Contribution of enzymes from rennet, starter bacteria and milk to proteolysis and flavour development in Gouda cheese. I. Description of cheese and aseptic cheese making techniques. Neth. Milk Dairy J. 31:120-133

Yilmaz, G., A. Ayar, and N. Akin. 2005. The effect of microbial lipase on the lipolysis during the ripening of Tulum cheese. J. Food Eng. 69:269-274. 